\title{
Chemosphere
}

May 2016, Volume 151 Pages 241-252

http://dx.doi.org/10.1016/j.chemosphere.2016.02.073

http://archimer.ifremer.fr/doc/00319/43047/

(c) 2016 Elsevier Ltd. All rights reserved.

\section{Microalgal sensitivity varies between a diuron-resistant strain and two wild strains when exposed to diuron and irgarol, alone and in mixtures}

\author{
Dupraz Valentin ${ }^{1}$, Coquillé Nathalie ${ }^{1,2,3,4}$, Ménard Dominique ${ }^{1}$, Sussarellu Rossana ${ }^{1}$, \\ Haugarreau Larissa ${ }^{1}$, Stachowski-Haberkorn Sabine ${ }^{1,{ }^{*}}$
}

${ }^{1}$ Ifremer, Laboratoire d'Écotoxicologie, rue de l'île d'Yeu, BP 21105, F-44311 Nantes Cedex 03, France

${ }^{2}$ Irstea, UR EABX, Centre de Bordeaux, 50 avenue de Verdun, F-33612 Cestas Cedex, France

${ }^{3}$ Université de Bordeaux, UMR 5805, EPOC, Laboratoire de Physico Toxico Chimie de

l'environnement, 351 Cours de la Libération, CS 10004, F-33405 Talence Cedex, France

${ }^{4}$ CNRS, UMR 5805, EPOC, Laboratoire de Physico Toxico Chimie de l'environnement, 351 Cours de la Libération, CS 10004, F-33405 Talence Cedex, France

${ }^{*}$ Corresponding author: Sabine Stachowski-Haberkorn, email address : Sabine.Stachowski.Haberkorn@ifremer.fr

\begin{abstract}
:
A wild strain of Chaetoceros calcitrans and wild and diuron-resistant strains of Tetraselmis suecica, were exposed to the PSII inhibitor herbicides diuron and irgarol, individually and in mixtures. The effects of three concentrations of diuron and irgarol and four binary mixtures were evaluated on doubling time, relative reactive oxygen species and lipid content by flow cytometry, and on photosynthetic efficiency by pulse amplitude modulated fluorescence.
\end{abstract}

In both wild strains, significant effects were observed for each molecule at the highest concentration tested: at irgarol $0.5 \mathrm{\mu g} \mathrm{L}^{-1}$, C. calcitrans was shown to be more sensitive than $T$. suecica $(+52 \%$ and $+19 \%$ in doubling time, respectively), whereas at diuron $5 \mu \mathrm{g} \mathrm{L}^{-1}, T$. suecica was more affected $(+125 \%$ in doubling time) than C. calcitrans $(+21 \%)$. Overall, irgarol had a higher toxicity at a lower concentration than diuron (no effect at diuron $0.5 \mathrm{\mu g} \mathrm{L}^{-1}$ ) for both wild strains. The strongest mixture (irgarol $0.5 \mu \mathrm{g} \mathrm{L}^{-1}+$ diuron $5 \mathrm{\mu g} \mathrm{L}^{-1}$ ) increased doubling time by $356 \%$ for T. suecica, thus showing amplified effects when the two compounds were mixed.

Sequencing of the diuron-resistant strain demonstrated a single mutation in the $p s b A$ gene coding sequence. Although resistance of this strain to diuron was confirmed with no effect at the highest diuron concentration, no resistance to irgarol was shown. In addition, the mutant strain exposed to the strongest mixture showed a 3.5-fold increase in doubling time compared with irgarol alone, thereby supporting the hypothesis of a biochemical interaction between these two compounds. 


\section{Highlights}

- Two microalgal species were exposed to irgarol, diuron, and mixtures of both. At $0.5 \mu \mathrm{g} \mathrm{L}{ }^{-1}$, irgarol was more toxic than diuron, for both species. A mutation was found in the $p s b A$ gene coding sequence of the diuron-resistant strain. The mutation induced no resistance to irgarol in the diuronresistant strain. Mixture (D5+10.5) induced stronger effects than I0.5 in the diuron-resistant strain.

Keywords : Microalgae, Herbicides, Antifouling, Irgarol, Diuron, Diuron resistance 


\section{Introduction}

Irgarol (2-methylthio-4-tertbutylamino-6-cyclopropylamino-s-triazine) and diuron (1-(3,4 dichlorophenyl)-3,3 dimethyl urea) are two biocides commonly used in copper-based antifouling paints to replace TBT (Tributyltin) (Manzo et al., 2006). Diuron has also been used as an herbicide in agriculture. The use of diuron as a biocide and herbicide was prohibited in France in 2008 (Directive biocide 98/8/CE and Arrêté du 21/08/2008). However, its persistence in the environment means that it is still found in rivers and coastal waters. In the Water Framework Directive (2000/60/EC), diuron, and later irgarol (Directive 2013/39/UE), were included in the list of "48 priority pollutants to be monitored in European waters", which will lead to their progressive prohibition over the next 20 years. While diuron is no longer used in most European countries, it is still of great concern in other countries, such as in Australia where it is known to be harmful to the Great Barrier Reef (Lewis et al., 2009; Holmes, 2012). In contrast, irgarol is still widely used in antifouling paints all around the world despite reports of high toxicity in some studies from the U.K. (Thomas et al., 2001; Chesworth et al., 2004), where its use in antifouling paints has been prohibited. Along the French coasts, average irgarol concentrations from 10 to 40 ng. $\mathrm{L}^{-1}$ were found in Arcachon Bay, while concentrations up to $0.1 \mu \mathrm{g} . \mathrm{L}^{-1}$ were reported in Arcachon port (Auby and Maurer, 2004). More recently, irgarol concentrations up to $0.186 \mu \mathrm{g} \cdot \mathrm{L}^{-1}$ were reported in Vilaine Bay (Caquet et al., 2013). In Singaporean coastal waters, irgarol concentrations in the range of 3 to $4 \mu \mathrm{g} . \mathrm{L}^{-1}$ have been reported (Basheer et al., 2002). As for diuron, concentrations from 11 to $33 \mathrm{ng} . \mathrm{L}^{-1}$ were reported in Mediterranean coastal waters (Munaron et al., 2012), and $0.268 \mu \mathrm{g} . \mathrm{L}^{-1}$ in Vilaine Bay (Caquet et al., 2013). The highest concentrations reported in European rivers and ground waters have been $0.279 \mu \mathrm{g} . \mathrm{L}^{-1}$ and $0.864 \mu \mathrm{g} . \mathrm{L}^{-1}$, respectively (Loos et al., 2009, 2010). In addition, diuron and irgarol have been measured at maximal concentrations of 2.583 and $0.824 \mu \mathrm{g} . \mathrm{L}^{-1}$, respectively, in careening areas of several ports (Cozic and Durand, 2013).

Irgarol, a triazine, and diuron, a phenylurea, both act as photosystem II (PSII) inhibitors: their binding action on the D1 protein in PSII prevents electron transfer between quinones $\mathrm{Q}_{\mathrm{A}}$ and $\mathrm{Q}_{\mathrm{B}}$, impeding Hill's reaction (Nimbal et al., 1996; Jones and Kerswell, 2003). As PSII structure is very well conserved among plants and microalgae, numerous non-target organisms could suffer deleterious effects if environmental pollution occurs (Readman et al., 1993).

Effects on phytoplankton have been recorded in a number of studies. Koutsaftis and Aoyama (2006) reported 72 $\mathrm{h} \mathrm{IC}_{50}$ values of $1.1 \mu \mathrm{g} . \mathrm{L}^{-1}$ and $36 \mu \mathrm{g} . \mathrm{L}^{-1}$ for irgarol and diuron respectively, on the growth of the microalga Chaetoceros gracilis. Nyström et al. (2002) established that irgarol concentrations ranging from 441 to 647 ng.L' ${ }^{1}$ were responsible for $50 \%$ photosynthesis inhibition in Lake Geneva phytoplankton. Larras et al. (2013) assessed the sensitivity of benthic diatoms to diuron and irgarol under both planktonic and benthic conditions. They established $\mathrm{EC}_{50}$, values of 4.27 and $10.07 \mu \mathrm{g} . \mathrm{L}^{-1}$ for planktonic conditions and 9.50 and $0.070 \mu \mathrm{g} . \mathrm{L}^{-1}$ for benthic conditions, for diuron and irgarol, respectively, based on the $96 \mathrm{~h}$ growth rate of the population. Devilla et al. (2005) established $\mathrm{EC}_{50}$ values based on $72 \mathrm{~h}$ cell number inhibition of 2.26 and $0.25 \mu \mathrm{g} . \mathrm{L}^{-1}$ for diuron and irgarol, respectively, on the microalga E. huxleyi. For diuron, tropical estuarine microalgae species Navicula sp. and $N$. pyriformis showed $\mathrm{EC}_{50}$ values of 7.8 and $8 \mu \mathrm{g} . \mathrm{L}^{-1}$, respectively, based on $72 \mathrm{~h}$ growth rate (Magnusson et al., 2008). In another study, Magnusson et al. (2010) found diuron $\mathrm{IC}_{50}$ values of 2.6, 2.01, 2.71 and $4.4 \mu \mathrm{g} . \mathrm{L}^{-1}$ 
for Navicula sp., N. pyriformis, P. tricornutum and C. closterium, respectively, based on photosynthetic efficiency.

In the environment, organisms are exposed to cocktails of chemicals, it is thus of interest to study the effects induced by mixtures of contaminants. Fernández-Alba et al. (2002) showed that a mixture of irgarol and diuron resulted in a synergistic interaction impacting three different organisms, including a microalga. Gatidou and Thomaidis (2007) showed that the harmful effects of interactions between irgarol and its metabolites were additive on phytoplankton, while the interaction between diuron and its metabolites was shown to be synergistic. Recently, Cedergreen (2014) reviewed the main interactions resulting from different types of pollutants: metals, pesticides and antifouling agents, revealing that synergistic interaction often occurred with antifouling mixtures.

Following chronic exposure to many different chemicals, genetic variants resistant to certain types of molecules might arise in some species. It was demonstrated that PSII inhibitor resistance was mainly due to a mutation in the gene sequence coding for the D1 protein (Erickson et al., 1989; Oettmeier, 1999). However, according to the literature available, such mutations were not involved in resistance to irgarol (Eriksson et al., 2009). Cells resistant to contaminants arise randomly by rare spontaneous pre-selective mutation during replication (Costas et al., 2001; López-Rodas et al., 2001). In the case of environmental pollution, such mutants would allow a population to become resistant (López-Rodas et al., 2009; Carrera-Martinez et al., 2011; Romero-Lopez et al., 2012). In the particular case of diuron resistance, it has been demonstrated that diuron itself was not responsible for the first appearance of resistant cells (López-Rodas et al., 2001).

The microalgae used in this study were the chlorophyte Tetraselmis suecica and the diatom Chaetoceros calcitrans. In addition to their use in aquaculture, both of these species are encountered in the temperate coastal waters of the East Atlantic. The testing of species from two different phyla enabled us to cover a broader range of potential responses to pesticide exposure. Furthermore, two different strains of $T$. suecica were used in this study: (i) a "wild" strain and (ii) a diuron-resistant strain (Stachowski-Haberkorn et al., 2013).

In order to understand to what extent environmental contamination with herbicides can affect microalgal populations, this study aimed:

1. To evaluate the toxicity of diuron and irgarol separately and to explore the effects of binary mixtures, on four physiological endpoints, using two species of microalgae.

2. To identify the mutation responsible for diuron resistance in the mutant strain of $T$. suecica.

3. To investigate the effects on the mutant strain of irgarol and of binary mixtures of both herbicides. To answer these questions, the impacts of irgarol and diuron (individually and in mixtures) were assessed on three strains of two marine phytoplankton species. The genetic basis of the resistance to diuron was investigated and effects of the herbicides were measured on four parameters. Growth, measured by doubling time $\left(T_{D}\right)$, is a parameter obviously related to the survival process in microalgae. Two other parameters related to the physiological status of the strains are expected to vary because of photosynthesis inhibition caused by diuron and irgarol: the photosynthetic efficiency $\left(\phi^{\prime}{ }_{\mathrm{M}}\right)$ and the relative reactive oxygen species (ROS; FL1 $\left.1_{\mathrm{ROS}}\right)$ content. Since the two phytoplankton species are commonly used in aquaculture, the relative lipid content (FL1 $\left.1_{\text {Lipids }}\right)$ was also measured, as it is related to the nutritive quality of the cells. 
One major interest of the present study is that, to our knowledge, no ecotoxicological studies have yet established the effects of herbicide mixtures toward both wild and resistant strains of the same phytoplankton species.

\section{Materials and methods}

\subsection{Chemical / toxicant preparation}

Irgarol (Irgarol Pestanal ${ }^{\circledR} \geq 98.4 \%$ ) and diuron (> 98\%) were purchased from Sigma Aldrich. Stock solutions of irgarol (500 mg. $\left.\mathrm{L}^{-1}\right)$ and diuron (500 mg. $\left.\mathrm{L}^{-1}\right)$ were then prepared in pure methanol. These solutions were diluted, using sterile ultra-pure water to make working solutions of $0.02 \mathrm{mg} . \mathrm{L}^{-1}\left(0.004 \%\right.$ methanol) and $0.06 \mathrm{mg} . \mathrm{L}^{-1}$ $\left(0.012 \%\right.$ methanol) for irgarol; and $0.1 \mathrm{mg} . \mathrm{L}^{-1}\left(0.02 \%\right.$ methanol) and $1 \mathrm{mg} . \mathrm{L}^{-1}(0.2 \%$ methanol) for diuron.

\subsection{Microalgal cultures}

The marine microalgae Tetraselmis suecica (CCMP 904) ("wild" strain: T_wild) and Chaetoceros calcitrans (CCMP 1315) ("wild" strain: $C_{-}$wild) were obtained from the Provasoli-Guillard National Center for Marine Algae and Microbiota (NCMA). A Tetraselmis suecica strain resistant to diuron (diuron-resistant mutant: T_mutant) was obtained from wild strain CCMP 904 after experiments performed by Stachowski-Haberkorn et al. (2013).

Microalgal cultures were maintained in sterile f/2 and f/2-silica medium (Guillard and Ryther, 1962; Guillard, 1975 ) at $17 \pm 1{ }^{\circ} \mathrm{C}$, in a thermostatic chamber ST5+ (POL-EKO-Aparatura ${ }^{\circledR}$, Poland) at $105 \mu \mathrm{mol} \cdot \mathrm{m}^{-2} \cdot \mathrm{s}^{-1}$ (Quantometer Li-Cor Li-250 equipped with a spherical sensor), with a dark:light cycle of 8:16 h. Cultures were grown in $100 \mathrm{~mL}$ round borosilicate sterile glass flasks previously heated to $450^{\circ} \mathrm{C}$ for $6 \mathrm{~h}$ and autoclaved 20 $\min$ at $121^{\circ} \mathrm{C}$.

For exposure experiments, cultures were grown in $60 \mathrm{~mL}$ sterile $\mathrm{f} / 2$ medium for $T$. suecica and $\mathrm{f} / 2$-Si medium for C. calcitrans: cultures were inoculated using stock cultures in exponential growth phase. The initial concentrations of cells were 20,000 cell. $\mathrm{mL}^{-1}$ for each species at the beginning of exposure.

\subsection{Exposure experiments}

Six-day exposure experiments were run. Preliminary experiments performed with each biocide separately showed that above $0.5 \mu \mathrm{g} . \mathrm{L}^{-1}$ irgarol or $5 \mu \mathrm{g} . \mathrm{L}^{-1}$ diuron, no algal growth was observed for at least one of the three strains. Each strain was therefore exposed to each biocide singly (irgarol: 0.05 (I0.05), 0.1 (I0.1) and 0.5 (I0.5) $\mu \mathrm{g} . \mathrm{L}^{-1}$; diuron: 0.5 (D0.5), 1 (D1) and 5 (D5) $\mu \mathrm{g} . \mathrm{L}^{-1}$ ) and to four binary mixtures of irgarol and diuron: $\mathrm{M}(\mathrm{D} 5+\mathrm{I} 0.5), \mathrm{M}(\mathrm{D} 5+\mathrm{I} 0.1), \mathrm{M}(\mathrm{D} 1+\mathrm{I} 0.5)$ and $\mathrm{M}(\mathrm{D} 1+\mathrm{I} 0.1)$. All concentrations are expressed as nominal concentrations. Only the two highest concentrations of each biocide were tested in the mixtures, as no effects were expected with the lowest concentrations. Two control treatments were included in the experiments. Control cultures $(\mathrm{C})$ contained only microalgae and culture medium; solvent-control cultures $\left(\mathrm{C}_{\mathrm{S}}\right)$ contained microalgae, culture medium and the highest methanol concentration corresponding to either $\mathrm{M}(\mathrm{D} 5+\mathrm{I} 0.5) \quad(0.0011 \%$ methanol) or diuron $5 \mu \mathrm{g} . \mathrm{L}^{-1}(0.001 \%$ methanol), which are more than 700 fold lower than the maximum methanol concentration recommended for algal bioassays (Abou-Waly, 2000). Five independent experiments 
were run in order to expose the three strains to all the treatments. Cultures were carried out in triplicate (exposed conditions) or in quadruplicate (control conditions). Every day, $500 \mu \mathrm{L}$ of each culture were sampled to measure cell concentrations. On the last day (day 6), when control cultures reached the end of exponential growth, a further $1400 \mu \mathrm{L}$ were sampled in each culture to assess the effects of exposures on different physiological endpoints: photosystem II effective quantum yield $(1000 \mu \mathrm{L})$, relative intracellular ROS content $(200 \mu \mathrm{L})$ and relative intracellular lipid content $(200 \mu \mathrm{L})$.

\subsection{Microalgal analysis using flow cytometry}

Samples were run on an Accuri C6 flow cytometer (Becton Dickinson Accuri $\left.{ }^{\mathrm{TM}}\right)$ equipped with a blue (488 $\left.\mathrm{nm}\right)$ and a red $(640 \mathrm{~nm})$ laser. Preliminary experiments made it possible to select the optimal protocol (staining duration and concentration) for each fluorescent dye and species.

\subsubsection{Doubling time measurement}

In order to measure the cell density daily in each culture, $500 \mu \mathrm{L}$ were sampled and fixed using glutaraldehyde (final concentration $0.25 \%$ ). Tubes were mixed and left for 15 minutes at room temperature in the dark before analysis. Preliminary experiments made it possible to choose the parameters best suited to discriminate the species: cells of $T$. suecica strains were counted on a FL1 (green fluorescence, 530/30 nm) vs. FL4 (red fluorescence, $675 / 25 \mathrm{~nm}$, chlorophyll-related) cytogram. Cells of $C$. calcitrans were counted on a SSC (Side Scatter) vs. FL3 (red fluorescence, $>670 \mathrm{~nm}$ ) cytogram.

Observation of culture samples by microscopy confirmed that $C$. calcitrans did not produce chains of cells under these experimental conditions. Counts were available directly in the BD Accuri ${ }^{\mathrm{TM}} \mathrm{C} 6$ software, including the analyzed volume.

For each culture, growth parameters were calculated as follows: the growth rate $\left(\mu\right.$, hours $\left.^{-1}\right)$ was the slope of the regression line from the plot of $\mathrm{Ln}$ (cell. $\left.\mathrm{mL}^{-1}\right)$ on time (hours). The doubling time $\left(\mathrm{T}_{\mathrm{D}}\right.$, hours) was calculated as: $\mathrm{T}_{\mathrm{D}}=\operatorname{Ln}(2) / \mu$.

\subsubsection{Reactive oxygen species (ROS)}

The fluorescent dye 2', $7^{\prime}$-dichlorodihydrofluorescein diacetate $\left(\mathrm{H}_{2} \mathrm{DCFDA}\right)$ was used to check for effects of irgarol, diuron and their mixtures on intracellular ROS production (Molecular probes, Eugene, OR, USA). $\mathrm{H}_{2}$ DCFDA is a non-polar dye which can enter the cells: in presence of $\mathrm{H}_{2} \mathrm{O}_{2}, \mathrm{ROO} \bullet$ or $\mathrm{ONOO}^{-}$, acetate groups are cleaved and oxidized by intracellular esterases, resulting in the conversion from non-fluorescent $\mathrm{H}_{2}$ DCFDA to highly fluorescent 2',7'-dichlrofluorescein (DCF). This fluorescent compound can be measured by green fluorescence (FL1, 530/30 nm). The following protocol was adapted from Stachowski-Haberkorn et al. (2013): a stock solution of $100 \mathrm{mM} \mathrm{H} \mathrm{H}_{2}$ DCFDA in dimethyl sulfoxide (DMSO) was used to make a $2 \mathrm{mM}$ working solution in phosphate-buffered saline $(137 \mathrm{mM} \mathrm{NaCl} ; 2.7 \mathrm{mM} \mathrm{KCl}, \mathrm{pH} 7.4,2 \%$ final DMSO concentration in the working solution). Preliminary experiments were carried out to determine the optimal $\mathrm{H}_{2}$ DCFDA concentration and incubation time to use for T. suecica and C. calcitrans cultures, using cultures exposed to $1 \mathrm{mM}$ or $100 \mu \mathrm{M}$ $\mathrm{H}_{2} \mathrm{O}_{2}$ (final concentration) as a positive control. In the present experiment, $\mathrm{H}_{2}$ DCFDA was used at a final 
concentration of $80 \mu \mathrm{M}(0.08 \%$ DMSO) in fresh $200 \mu \mathrm{L}$ samples. Samples were incubated in the dark at room temperature for $30 \mathrm{~min}$ before analysis.

\subsubsection{Relative intracellular lipid content}

The relative intracellular lipid content was estimated by the use of a green lipophilic fluorochrome: 4,4-difluoro1,3,5,7-tetramethyl-4-bora-3a,4a-diaza-s-indacene (BODIPY ${ }^{505 / 515}$ Life Technologies ${ }^{\circledR}$, Carlsbad, CA, USA). This fluorescent compound is accumulated in the intracellular lipid bodies (which are morphologically diverse) by a diffusion mechanism and subsequent trapping. This dye easily crosses cell and organelle membranes due to its high oil/water partition coefficient (Akimoto and Mimuro, 2007; Cooper et al., 2010). BODIPY ${ }^{505 / 515}$ can be measured by green fluorescence (FL1, 530/30 nm). The following protocol was adapted from Brennan et al. (2012): a working solution of $12 \mu \mathrm{g} . \mathrm{L}^{-1}$ was prepared from a $5000 \mathrm{mg} . \mathrm{L}^{-1}$ stock solution in pure DMSO. BODIPY was used at $0.075 \mu \mathrm{g} . \mathrm{L}^{-1}$ final concentration $\left(0.6 \%\right.$ DMSO) for $C$. calcitrans and $0.12 \mu \mathrm{g} . \mathrm{L}^{-1}$ final concentration (1.0\% DMSO) for T. suecica in fresh $200 \mu \mathrm{L}$ samples. Before analysis, samples were incubated in the dark at room temperature for 6 and 5 minutes for $C$. calcitrans and T. suecica, respectively.

\subsection{Photosystem II effective quantum yield}

Photosystem II effective quantum yield (operational yield $=\phi_{\mathrm{M}}{ }_{\mathrm{M}}$ ) was measured by Pulse Amplitude Modulated (PAM) fluorescence using an Aquapen-C AP-C 100 fluorometer (Photon system Instruments ${ }^{\circledR}$, Drasov, Czech Republic). Measurements were made on $2 \mathrm{~mL}$ of diluted cultures (1:2 dilution in culture medium) in light adapted conditions (light intensity of the culture chamber). Three measurements were performed for each culture and a mean taken of these values.

\subsection{D1 protein $\mathrm{mRNA}$ sequencing}

Triplicate 50-mL cultures of $T_{-}$wild and $T_{-}$mutant were grown in control conditions for six days in order to extract total RNA. Cells were centrifuged at $4500 \mathrm{~g}$ for $10 \mathrm{~min}$, washed in sterile $\mathrm{f} / 2$ medium and re-centrifuged prior to adding $1.5 \mathrm{~mL}$ Trizol (Ambion, Life Technologies). Total RNA was extracted according to the Trizol manufacturer's instructions. RNA concentrations were determined using an ND-1000 spectrophotometer (Thermo Scientific, Waltham MA, USA) at $260 \mathrm{~nm}$. RNA integrity was assessed on an Agilent bioanalyzer using RNA 6000 Nano kits (Agilent Technologies, Santa Clara, CA, USA), according to the manufacturer's instructions. Reverse transcription was carried out with the High-Capacity cDNA Reverse Transcription Kit (Applied Biosystems, Life Technologies), according to manufacturer's instructions, on $2 \mu \mathrm{g}$ total RNA. Primers (Table 1) were designed on the T. suecica D1 protein complete CDS (Genbank DQ173249) using PrimerBLAST NCBI tools. The protein was divided into two regions (A and B) in order to obtain PCR products between 500 and $600 \mathrm{bp}$. For each T. suecica strain and primer pair, PCR reactions were performed in triplicate using NEBNext High Fidelity 2X Master mix (New England Biolabs, Ipswich, MA USA) on $3 \mu \mathrm{L}$ cDNA with $25 \mu \mathrm{M}$ of primers. The thermal cycler was programmed, according to manufacturer's instructions, as follows: $98^{\circ} \mathrm{C}$ for 30 seconds for initial denaturation; 15 cycles at $98^{\circ} \mathrm{C}$ for 10 seconds, $65^{\circ} \mathrm{C}$ for 30 seconds and $72^{\circ} \mathrm{C}$ for 30 seconds; then $72^{\circ} \mathrm{C}$ for $5 \mathrm{~min}$ for the final extension. PCR products were purified with USB ExoSAP-IT PCR Product Cleanup (Affymetryx, Santa Clara, CA, USA) and sequenced in a facility with a Sanger ABI 3730xl 
(Applied Biosystems, Life Technologies), using the primers in Table 1. Sequences were aligned with Clustal W implemented in MEGA 6 software (Tamura et al., 2013).

\subsection{Statistical analysis}

One-way ANOVAs were performed on each strain/chemical combination to check for significant differences in growth, yield, relative intracellular ROS level and lipid content between control and exposed cultures. A $p$-value $<0.05$ was considered statistically significant. When significant differences were observed, a multiple range Newman-Keuls test was used to compare means. All statistical analyses were performed using Statistica (StatSoft, Inc., version 10).

\section{Results}

Neither methanol concentration showed a significant effect on the studied parameters (data not shown) compared with the control without solvent, whatever the species and strain. The results obtained for each species/strain are therefore presented without the solvent-controls. In Table 2, results are expressed as mean values ( \pm standarderror, SE) of raw data. In all the figures, results are shown as the percentage of variation of exposed samples compared with the control without solvent (C).

\subsection{Chaetoceros calcitrans}

\subsubsection{Toxicity of single herbicides}

Among the three concentrations of diuron tested, only the highest (D5) showed significant effects on the four parameters measured (Table 2), namely: doubling time $T_{D}$, photosynthetic efficiency $\phi^{\prime}{ }_{M}$, reactive oxygen species-related relative fluorescence $\mathrm{FL} 1_{\mathrm{ROS}}$ and lipid-related relative fluorescence $\mathrm{FL} 1_{\text {Lipids. }}$. In the D5-exposed cultures, while $\mathrm{T}_{\mathrm{D}}$ increased by $21 \pm 2.2 \%(p=0.0002)$ compared to the control, the three other parameters decreased (Figure 1).

Like diuron, irgarol showed no significant effect at the two lowest concentrations (Table 2). At $0.5 \mu \mathrm{g} . \mathrm{L}^{-1}$, a significant increase of $\mathrm{T}_{\mathrm{D}}$ was demonstrated $(+52 \pm 3.1 \%, p=0.0002)$; significant decreases were noticed in $\phi_{\mathrm{M}}$ and FL $1_{\text {ROS }}$, although no significant effect was found on FL1 $1_{\text {Lipids }}($ Table 2$)$.

\subsubsection{Toxicity of herbicide mixtures}

The four mixtures used in this study significantly affected C. calcitrans for at least one parameter out of the four measured (Table 2, Figure 1). Indeed, while $\mathrm{M}(\mathrm{D} 1+\mathrm{I} 0.1)$ induced only a single significant decrease in $\mathrm{FL} 1_{\text {Lipids, }}$, the three other mixtures had significant effects on all parameters. $\mathrm{M}(\mathrm{D} 5+\mathrm{I} 0.5)$ and $\mathrm{M}(\mathrm{D} 1+\mathrm{I} 0.5)$, induced greater effects on $\mathrm{T}_{\mathrm{D}}$ and $\phi_{\mathrm{M}}{ }_{\mathrm{M}}$ than $\mathrm{M}(\mathrm{D} 5+\mathrm{I} 0.1)$ : $\mathrm{T}_{\mathrm{D}}$ was increased by $87 \pm 11 \%(p=0.0002)$ and by $56 \pm 2.2 \%$ $(p=0.0003)$ when the cultures were exposed to $\mathrm{M}(\mathrm{D} 5+\mathrm{I} 0.5)$ and $\mathrm{M}(\mathrm{D} 1+\mathrm{I} 0.5)$, respectively. The increase induced by $\mathrm{M}(\mathrm{D} 5+\mathrm{I} 0.1)$ was lower $(+35 \pm 5.9 \%, p=0.0021)$. In the same way, these three mixtures caused 
significant decreases in $\phi^{\prime}{ }_{\mathrm{M}}$ from $-26 \pm 0.8 \%(p=0.0002)$, to $-14 \pm 2.9 \%(p=0.0002)$ (Figure 1$)$. FL $1_{\mathrm{ROS}}$ and FL1 $1_{\text {Lipids }}$ were affected to nearly the same extent by the three mixtures, with decreases around $60 \%(p=0.0002$ for all concentrations and both parameters).

\subsection{Tetraselmis suecica}

\subsubsection{Wild strain}

\subsubsection{Toxicity of single herbicides}

Among the three diuron concentrations tested, only the highest (D5) significantly affected all parameters, the greatest effect being on $\mathrm{T}_{\mathrm{D}}(+125 \pm 24.3 \%, p=0.0003)$ (Table 2 and Figure 2). At $1 \mu \mathrm{g} . \mathrm{L}^{-1}$, diuron induced a significant increase in $\mathrm{FL}_{\mathrm{ROS}}$ by $10 \pm 4.2 \%(p=0.019)$ and a significant decrease in $\mathrm{FL} 1_{\text {Lipids }}$ by $16 \pm 3.4 \%$ $(p=0.028)$, when no effect was detected on $\mathrm{T}_{\mathrm{D}}$ or $\phi^{\prime}{ }_{\mathrm{M}}$. At $0.5 \mu \mathrm{g} \cdot \mathrm{L}^{-1}$ diuron (Table 2$)$, only a significant decrease in $\mathrm{FL}_{\text {Lipids }}$ was demonstrated (Figure 2).

After exposure to irgarol $0.5 \mu \mathrm{g} . \mathrm{L}^{-1}$, significant effects were shown on the four parameters (Table 2 and Figure 2). $\mathrm{T}_{\mathrm{D}}$ and $\mathrm{FL} 1_{\mathrm{ROS}}$ were increased $\left(+19 \pm 2 \%\right.$ for $\left.\mathrm{T}_{\mathrm{D}}, p=0.0002\right)$, while $\phi{ }_{\mathrm{M}}$ and $\mathrm{FL} 1_{\text {Lipids }}$ were decreased (Figure 2). With irgarol $0.05 \mu \mathrm{g} . \mathrm{L}^{-1}$, slight significant effects were noticed on $\phi_{\mathrm{M}}{ }_{\mathrm{M}}$, which was mildly stimulated, and $\mathrm{FL}_{\mathrm{ROS}}$, which was lower than the control.

\subsubsection{Toxicity of herbicide mixtures}

Among the four mixtures tested in this study, three induced significant deleterious effects on all parameters measured (Table 2). The most concentrated mixture, $\mathrm{M}(\mathrm{D} 5+\mathrm{I} 0.5)$, led to a $356 \pm 35 \%(p=0.0002)$ increase in $\mathrm{T}_{\mathrm{D}}$, as well as a $95 \pm 8 \%(p=0.0002)$ increase in $\mathrm{FL}_{\mathrm{ROS}}$ (Figure 2). The $\phi_{\mathrm{M}}$ and $\mathrm{FL} 1_{\text {Lipids }}$ decreased significantly by $29 \pm 1.2 \%(p=0.0002)$ and $37 \pm 2.6 \%(p=0.0003)$, respectively.

While the increase in $\mathrm{T}_{\mathrm{D}}$ was more than two-fold lower for $\mathrm{M}(\mathrm{D} 5+\mathrm{I} 0.1)(150 \pm 8.9 \%, p=0.0003)$ and four-fold lower for $\mathrm{M}(\mathrm{D} 1+\mathrm{I} 0.5)(81 \pm 2.2 \%, p=0.008)$, the effects on $\mathrm{FL}_{\text {Lipids }}$ remained at the same level as for $\mathrm{M}(\mathrm{D} 5+\mathrm{I} 0.5)$ (around $-35 \%, p=0.0003$ for both) (Figure 2). The toxicity gradient was also observed in $\phi^{\prime}{ }_{\mathrm{M}}$ with a $23 \pm 0.6 \%(p=0.0002)$ decrease for $\mathrm{M}(\mathrm{D} 5+\mathrm{I} 0.1)$ and a $15 \pm 0.5 \%(p=0.0002)$ decrease for $\mathrm{M}(\mathrm{D} 1+\mathrm{I} 0.5)$, which was half the decrease observed for $\mathrm{M}(\mathrm{D} 5+\mathrm{I} 0.5)$. $\mathrm{FL} 1_{\mathrm{ROS}}$ also showed the same toxicity gradient between mixtures, with $79 \pm 5.8 \%(p=0.0002)$ and $66 \pm 4.4 \%(p=0.0003)$ increases for $\mathrm{M}(\mathrm{D} 5+\mathrm{I} 0.1)$ and $\mathrm{M}(\mathrm{D} 1+\mathrm{I} 0.5)$, respectively.

Finally, the least toxic mixture, $\mathrm{M}(\mathrm{D} 1+\mathrm{I} 0.1)$, was only responsible for a slight but significant decrease in FL1 $1_{\text {Lipids }}$ (Figure 2).

\subsubsection{Diuron-resistant strain}

\subsubsection{D1 protein mRNA sequencing}

The sequence alignment in the resistant strain revealed a mutation from $\mathrm{G}$ to $\mathrm{A}$ in the quinone binding domain (amplified with primer pair B) at position 661 of the CDS (Figure 3A). This mutation corresponded to a change 
in the codons from GTA to ATA, leading to a switch in the amino acid sequence from Valine (V) to Isoleucine (I) at position 221 of the protein (Figure 3B). No other mutations were observed in the sequenced samples.

\subsubsection{Toxicity of single herbicides}

Diuron exposure did not show any significant effect on the mutant strain at the three concentrations tested (Table 2), except a slight decrease of $\phi^{\prime}{ }_{M}$ at $5 \mu$ g. $L^{-1}$ (Figure 4).

Irgarol exposure induced significant effects on the mutant strain, in particular at the highest concentration tested $\left(0.5 \mu \mathrm{g} . \mathrm{L}^{-1}\right)$ : $\mathrm{T}_{\mathrm{D}}$ and $\mathrm{FL} 1_{\text {Ros }}$ increased significantly $\left(+19 \pm 3.4 \%\right.$ for $\left.\mathrm{T}_{\mathrm{D}}, p=0.0002\right)$, whereas $\phi_{\mathrm{M}}{ }_{\mathrm{M}}$ and $\mathrm{FL} 1_{\mathrm{Lipids}}$ decreased significantly (Figure 4). A slight but significant decrease of $\phi^{\prime}{ }_{M}$ was obtained with the lowest concentration of irgarol $\left(0.05 \mu \mathrm{g} \cdot \mathrm{L}^{-1}\right)$.

\subsubsection{Toxicity of herbicide mixtures}

The four mixtures tested did not impact the mutant strain in the same way. On the one hand, M(D5+I0.5) and $\mathrm{M}(\mathrm{D} 1+\mathrm{I} 0.5)$ significantly affected all parameters tested (Table 2). $\mathrm{M}(\mathrm{D} 5+\mathrm{I} 0.5)$ was the most toxic mixture, which induced an increase of $\mathrm{T}_{\mathrm{D}}$ and $\mathrm{FL} 1_{\mathrm{ROS}}$ by $66 \pm 6.7 \%(p=0.0002)$ and $70 \pm 7.9 \%(p=0.0002)$, respectively, while $\phi^{\prime}{ }_{M}$ and $F L 1_{\text {Lipids }}$ decreased (Figure 4). In comparison, $\mathrm{M}(\mathrm{D} 1+\mathrm{I} 0.5)$ exposure resulted in lower toxicity, with an increase in $\mathrm{T}_{\mathrm{D}}$ by $28 \pm 2.8 \%(p=0.0002)$. $\mathrm{FL}_{\mathrm{ROS}}$ and $\phi^{\prime}{ }_{\mathrm{M}}$ also indicated lower effects of $\mathrm{M}(\mathrm{D} 1+\mathrm{I} 0.5)$.

On the other hand, the two other mixtures did not cause strong deleterious effects on this strain, as the only significant effect was a slightly lower photosynthetic efficiency with $\mathrm{M}(\mathrm{D} 5+\mathrm{I} 0.1)$ and $\mathrm{M}(\mathrm{D} 1+\mathrm{I} 0.1)$ (Figure 4). No significant effect was detected on growth, FL1 $1_{\text {Ros }}$ or FL $1_{\text {Lipids }}$ (Table 2) with these two mixtures.

\section{Discussion}

\subsection{Herbicide toxicity towards the two wild strains}

The two microalga species were not affected in the same way by the exposure to the herbicides. Chaetoceros calcitrans, when exposed to irgarol $0.5 \mu \mathrm{g} . \mathrm{L}^{-1}$, showed an increase in $\mathrm{T}_{\mathrm{D}}$ that was 2.5 -fold higher than that for Tetraselmis suecica, highlighting a higher sensitivity of the diatom to irgarol. This increase corresponded to a $144 \mathrm{~h}$ growth rate inhibition of $34.3 \pm 1.3 \%$ for $C$. calcitrans and $16.1 \pm 1.4 \%$ for $T$. suecica (data not shown), showing that for both species, $144 \mathrm{~h} \mathrm{EC}_{50}$ would be higher than $0.5 \mu \mathrm{g} . \mathrm{L}^{-1}$. Exposure to diuron $5 \mu \mathrm{g} . \mathrm{L}^{-1}$ resulted in a six-fold higher increase in $\mathrm{T}_{\mathrm{D}}$ for $T$. suecica compared with the diatom, corresponding to $144 \mathrm{~h}$ growth rate inhibition of $17.5 \pm 1.6 \%$ for $C$. calcitrans and $54.5 \pm 4.8 \%$ for $T$. suecica, the latter being close to the $\mathrm{EC}_{50}$. In comparison, $\mathrm{EC}_{50}$ based on $72 \mathrm{~h}$ growth rate for Navicula sp and $N$. pyriformis exposed to diuron were 7.8 and 8 $\mu \mathrm{g} . \mathrm{L}^{-1}$ (Magnusson et al., 2008). Buma et al. (2009) determined irgarol $\mathrm{EC}_{50}$ (based on $72 \mathrm{~h}$ growth rate) from $0.46 \pm 0.09$ to $2.44 \pm 0.68 \mu \mathrm{g} . \mathrm{L}^{-1}$ for four marine microalga species. Devilla et al. (2005) reported $72 \mathrm{~h} \mathrm{EC}_{50}$ of $0.25 \mu \mathrm{g} . \mathrm{L}^{-1}$ irgarol and $2.26 \mu \mathrm{g} . \mathrm{L}^{-1}$ diuron on the growth of the microalga Emiliania huxleyi, while $96 \mathrm{~h} \mathrm{EC}_{50}$ of $0.57 \mu \mathrm{g} . \mathrm{L}^{-1}$ irgarol and $5.9 \mu \mathrm{g} . \mathrm{L}^{-1}$ diuron were measured on the growth of the diatom Skeletonema costatum (Bao et al., 2011). Our results are thus in agreement with the data available in the literature. 
Diuron and irgarol both target photosystem II on which microalgae rely for photosynthesis to produce their organic matter and to divide. Photosynthesis inhibition consequently induces growth inhibition, as shown by these results. Furthermore, other side effects occur due to the action of such molecules on photosystem II. Harmful free radicals such as hydrogen peroxide are produced when the photochemical pathway is blocked (Fuerst and Norman, 1991; Oettmeier, 1992) as it could be by PSII inhibitors. The two molecules tested in the present study were thus particularly expected to induce oxidative stress in the exposed cells. When looking at ROS intracellular levels expressed by $F L 1_{\text {ROS }}$ for each wild strain, the response induced on FL $1_{\text {ROS }}$ by either diuron or irgarol at the highest concentration $\left(5 \mu \mathrm{g} . \mathrm{L}^{-1}\right.$ and $0.5 \mu \mathrm{g} . \mathrm{L}^{-1}$, respectively) was in the same range: a decrease of about $60 \%$ for the diatom and an increase of about $40 \%$ for the chlorophyte. Unlike T. suecica, in which $\mathrm{FL} 1_{\mathrm{ROS}}$ was enhanced, indicating an increase of intracellular reactive oxygen species content, the significant decrease of about $60 \%$ observed in $\mathrm{FL} 1_{\mathrm{ROS}}$ for the diatom indicates a decrease of intracellular ROS content. Preliminary experiments made it possible to validate the use of $\mathrm{H}_{2}$ DCFDA with this species, using hydrogen peroxide $(1 \mathrm{mM}$ and $100 \mu \mathrm{M})$ as a positive control, and showing an increase in FL1 $1_{\text {Ros }}$ (data not shown). Diatoms possess an effective antioxidant system against photo-inhibition and photo-oxidation: it has been demonstrated that fucoxanthin, which is a major carotenoid pigment in diatoms (Pennington et al., 1988), has a very effective ROS scavenging activity (Sachindra et al., 2007; Xia et al., 2013). As a consequence, the decrease of ROS content observed with $C$. calcitrans in the present study could be due to the high ROS scavenging activity of fucoxanthin. Another hypothesis, which could be related to the last, is that the biocides trigger a ROS scavenging system involving enzymes such as SOD and CAT through their inhibition of photosynthesis. Thus, it would be interesting to quantify the fucoxanthin within diatom cells and measure enzymatic activities of SOD and CAT to test these hypotheses.

When herbicide exposure inhibits photosynthesis, ATP production is compromised, impairing biochemical pathways such as lipid synthesis. BODIPY ${ }^{505 / 515}$ was used to measure the relative lipid content in microalgal cells. BODIPY ${ }^{505 / 515}$ stains neutral lipids, which correspond to oil droplets that accumulate inside cells over time (Hu et al., 2008). T. suecica was affected at all diuron concentrations tested, even the lowest (0.5 $\mu$ g. $\mathrm{L}^{-1}$ diuron). For C. calcitrans, $\mathrm{FL}_{\mathrm{Lipids}}$ decrease was two-fold greater than for the cholorophyte at the highest concentration ( $5 \mu \mathrm{g} . \mathrm{L}^{-1}$ diuron), but no significant effects were observed at lower concentrations. These results indicate that diuron induced greater effects than irgarol on relative lipid content in both strains. It could be interesting to make further studies on this lipid decrease, to determine and quantify which lipid classes are impacted. This would provide information about the effects of such herbicides on the nutritive quality of these species, since they are commonly used in aquaculture.

Considering growth as the most integrative parameter, $C$. calcitrans appeared to be more sensitive to irgarol than T. suecica, which had a higher sensitivity to diuron. However, the concentrations used to assess diuron toxicity were ten-fold higher than the concentrations used to test irgarol, thus illustrating how irgarol has a higher absolute toxicity than diuron, whatever the microalgal species. Several studies already reported higher toxicity of irgarol toward microalgae in comparison with diuron (Devilla et al., 2005; Gatidou and Thomaidis, 2007). The higher toxicity of irgarol seems likely due to its higher affinity for the $\mathrm{Q}_{\mathrm{B}}$ niche and a higher toxicokinetic (Chesworth et al., 2004).

Regarding the effects on the coastal water microalgae T. suecica and the diatom P. tricornutum, Huertas et al. (2010) demonstrated that the chlorophyte $T$. suecica was more tolerant of simazine (a triazine) than the diatom. 
Another study found the triazine atrazine to be more toxic to the chlorophytes than to diatoms (Seguin et al., 2001). From the data available in literature, it is still unclear whether diatoms are more sensitive to triazine than other microalgae, since this sensitivity can vary depending on the herbicide (Suresh Kumar et al., 2014) and the diatom species (Larras et al., 2014). Moreover, following a study from Weiner et al. (2004), the sensitivity of microalgae could vary depending on the herbicide uptake, which is itself related to intrinsic properties of the species, like biovolume or surface area.

\subsection{Toxicity of single herbicides vs. mixtures in the two wild strains}

The sensitivity of these species to the mixtures followed the same trend as the single molecules. Although $\mathrm{M}(\mathrm{D} 5+\mathrm{I} 0.5)$ was the most toxic mixture for both species, the increase in doubling-time was four-fold higher for T. suecica than for $C$. calcitrans. When looking at the increase in doubling-time, it appeared that $T_{-}$wild was more sensitive to mixtures containing diuron $5 \mu \mathrm{g} . \mathrm{L}^{-1}$. On the contrary, $C$. calcitrans was more affected by mixtures containing irgarol $0.5 \mu \mathrm{g} . \mathrm{L}^{-1}$. These results corroborate the effects obtained with the single molecules. Impacts on $\phi^{\prime}{ }_{M}$ were within the same range for both species and revealed a similar level of toxicity than $T_{D}$ for $\mathrm{M}(\mathrm{D} 5+\mathrm{I} 0.5), \mathrm{M}(\mathrm{D} 5+\mathrm{I} 0.1)$ and $\mathrm{M}(\mathrm{D} 1+\mathrm{I} 0.5)$. The decrease in FL1 $1_{\text {Lipids }}$ was almost two-fold higher for the diatom. An interesting pattern was obtained for FL1 $1_{\text {Lipids }}$ in both species, as the same decrease was caused by the three strongest mixtures (about $60 \%$ for the diatom and 35\% for the chlorophyte). There might be a threshold beyond which FL1 $1_{\text {Lipids }}$ cannot decrease further, corresponding to the lowest concentration of oil droplets allowed by the cell and/or to the background fluorescence value obtained with BODIPY ${ }^{505 / 515}$ for each species. As shown by the single-herbicide exposures, $\mathrm{FL} 1_{\mathrm{ROS}}$ results were the opposite between the two species: a threshold was shown in the diatom responses, with the same decrease in $\mathrm{FL} 1_{\mathrm{ROS}}$ for $\mathrm{M}(\mathrm{D} 5+\mathrm{I} 0.5), \mathrm{M}(\mathrm{D} 5+\mathrm{I} 0.1)$ and $\mathrm{M}(\mathrm{D} 1+\mathrm{I} 0.5)$. In contrast, $T$. suecica showed an increasing gradient in the $\mathrm{FL} 1_{\mathrm{ROS}}$ from $\mathrm{M}(\mathrm{D} 1+\mathrm{I} 0.5)$ (about $66 \%$ ) to $\mathrm{M}(\mathrm{D} 5+\mathrm{I} 0.5)$ (almost 100\%), thus indicating an enhanced ROS production in the exposed cells, which is consistent with the results observed on $T_{D}$ and $\phi{ }^{\prime}$.

When comparing the toxicity of single herbicides and mixtures, $\mathrm{M}(\mathrm{D} 1+\mathrm{I} 0.5)$ was significantly more toxic than irgarol $0.5 \mu \mathrm{g} . \mathrm{L}^{-1}$ to $T_{-}$wild. The only difference between these two treatments was the addition of $1 \mu \mathrm{g} . \mathrm{L}^{-1}$ diuron to $\mathrm{M}(\mathrm{D} 1+\mathrm{I} 0.5)$, which itself was not harmful to the T. suecica wild strain. Finally, when $\mathrm{M}(\mathrm{D} 5+\mathrm{I} 0.5)$ toxicity was compared with added single-herbicide toxicities, it showed a higher toxicity on $T_{D}$ than the two biocides together, while the impact on $\phi^{\prime}{ }_{\mathrm{M}}, \mathrm{FL} 1_{\mathrm{ROS}}$ and $\mathrm{FL} 1_{\text {Lipids }}$ remained nearly the same as for single-herbicide exposures. For the diatom C. calcitrans, $\mathrm{M}(\mathrm{D} 5+\mathrm{I} 0.5)$ was as toxic as the added toxicity of the two single biocides on $\mathrm{T}_{\mathrm{D}}$ and $\phi^{\prime}{ }_{\mathrm{M}}$.

When looking at the percentage of variation of doubling time in comparison with the control, the effects of $\mathrm{M}(\mathrm{D} 5+\mathrm{I} 0.5)$ and $\mathrm{M}(\mathrm{D} 1+\mathrm{I} 0.5)$ were stronger than a simple addition on the chlorophyte: the added effect of $\mathrm{D} 5$ $\left(125 \pm 24.3 \%\right.$ increase in $\left.\mathrm{T}_{\mathrm{D}}\right)$ and $\mathrm{I} 0.5\left(19 \pm 2 \%\right.$ increase in $\left.\mathrm{T}_{\mathrm{D}}\right)$ should be around $144 \%$ increase in doubling time, when M(D5+I0.5) was responsible for a $356 \pm 35 \%$ increase. Similarly, the summed effects of D1 (no significant effects on $\left.\mathrm{T}_{\mathrm{D}}\right)$ and $\mathrm{I} 0.5\left(19 \pm 2 \%\right.$ increase in $\left.\mathrm{T}_{\mathrm{D}}\right)$ should be around $19 \%$, while $\mathrm{M}(\mathrm{D} 1+\mathrm{I} 0.5)$ was responsible for a $81 \pm 2.2 \%$ increase. These results might thus indicate a possible synergistic interaction between these two herbicides, as already reported elsewhere (Fernández-Alba et al., 2002; Koutsaftis and Aoyama, 2006). However, the use of a Concentration Addition (CA) model (Loewe and Muischnek, 1926) is required to prove the additive or synergistic interaction between the two biocides. 
Considering the set of parameters, the toxicity of mixtures and single herbicides that induced significant effects on these two species can be ranked as follows:

$$
\text { C_wild: } \mathrm{M}(\mathrm{D} 5+\mathrm{I} 0.5)>\mathrm{M}(\mathrm{D} 1+\mathrm{I} 0.5) \approx \mathrm{I} 0.5>\mathrm{M}(\mathrm{D} 5+\mathrm{I} 0.1)>\mathrm{D} 5
$$

T_wild: $\mathrm{M}(\mathrm{D} 5+\mathrm{I} 0.5)>\mathrm{M}(\mathrm{D} 5+\mathrm{I} 0.1) \approx \mathrm{D} 5 \geq \mathrm{M}(\mathrm{D} 1+\mathrm{I} 0.5)>\mathrm{I} 0.5$

When mixed together at the highest concentrations tested, these two herbicides show a higher toxicity than the sum of single toxicities for $T$. suecica and it is very likely that other molecules from the same family or with a similar mode of action would further increase the toxicity of such mixtures (Cedergreen, 2014).

\subsection{PsbA gene mutation: resistance to diuron and comparison with the wild strain}

The appearance of species or strains resistant or tolerant to xenobiotics is an increasing problem (López-Rodas et al., 2009; Marvá et al., 2010) and illustrates the selective pressure exerted by pollutants on organisms. For example, in cases of severe pollution in an aquatic environment, the selection pressure exerted will permit the survival of resistant variants among the natural phytoplankton community. However, the surviving community will have a reduced genetic diversity that may not be sufficient to deal with other ecosystem disturbances, such as those expected with climate change for example. In addition, resistance to a pollutant is usually accompanied by diminished primary production (Lardans et al., 1998) that could eventually impair the ecosystem productivity. Some microalga species show resistance to photosynthesis inhibitor herbicides: in the case of PSII inhibitors that specifically bind to D1 protein, the resistance was shown to be due to mutations in the $p s b A$ gene coding for this protein binding site (Galloway and Mets, 1984; Erickson et al., 1985, 1989). In the present study, the mutation found in the diuron-resistant strain of T. suecica was caused by a single nucleotide modification in the $p s b A$ sequence, and resulted in a change from V to I, as already reported (Erickson et al., 1985). The additional methyl group in Isoleucine could prevent the binding of diuron to the D1 protein by steric blockage (Wildner et al., 1990). This particular mutation was previously shown to confer a resistance to diuron in Chlamydomonas reinhardtii (Oettmeier, 1999). Some authors demonstrated that adaptation of microalgae to herbicides might be the result of pre-selective mutations (López-Rodas et al., 2001; Marvá et al., 2010).

In order to assess whether the mutation could affect strain response to another PSII inhibitor, both T. suecica strains were exposed to diuron and irgarol. Unlike $T_{-}$wild, which was heavily affected by diuron $5 \mu \mathrm{g} . \mathrm{L}^{-1}$ exposure ( $125 \%$ increase in $\mathrm{T}_{\mathrm{D}}$ ), $T_{-}$mutant was not affected by diuron, regardless of the concentration used. Even though exposure to irgarol $0.5 \mu \mathrm{g} . \mathrm{L}^{-1}$ induced an increase of $19 \%$ of $\mathrm{T}_{\mathrm{D}}$ in both $T_{-}$wild and $T_{-}$mutant, the effects on FL1 $1_{\text {ROS }}$ and FL1 $1_{\text {Lipids }}$ in $T_{-}$mutant were lower compared with $T_{-}$wild. The lower effects on ROS and lipids in $T_{-}$mutant might be a side-effect of the mutation. The triazine irgarol significantly impacted all studied parameters at the highest concentration in the mutant strain, implying that the mutation did not prevent its toxic action, i.e. it did not prevent irgarol from binding to the D1 protein. The two herbicides share the same mode of action, inhibiting electron transfer between $\mathrm{Q}_{\mathrm{A}}$ to $\mathrm{Q}_{\mathrm{B}}$ by reversely-binding on the $\mathrm{Q}_{B}$ binding site on the $\mathrm{D} 1$ protein (Tischer and Strotmann, 1977; Giardi and Pace, 2005). One reason why the mutation prevents diuron but not irgarol from binding to the D1 protein could be that the two molecules do not necessarily have the same toxicological behavior (Gramatica et al., 2001; Borgert et al., 2004) because they come from different chemical families (phenylureas for diuron and triazines for irgarol). Indeed, the two classes of compounds are structurally 
different, as demonstrated by Gramatica et al. (2001), and their binding niches therefore differ slightly (Geissbühler et al., 1975; Ohad et al., 1990).

Recently, tolerance to irgarol in marine periphyton was found to be based not on amino acid substitution, but rather on increased D1 degradation (Eriksson et al., 2009). This latter mechanism seems to be linked to the nonconserved amino acid region (PEST region) involved in regulating D1 protein degradation. In any case, in the present study, this region did not show any differences between the two T. suecica strains.

The effects of mixtures were also investigated to further examine the toxicity pattern obtained with the single molecules. As expected, the wild strain was a lot more sensitive to the mixtures $\mathrm{M}(\mathrm{D} 5+\mathrm{I} 0.5)$ and $\mathrm{M}(\mathrm{D} 5+\mathrm{I} 0.1)$ than the mutant strain. Regarding the wild strain, $M(D 5+I 0.5)$ induced an increase in $T_{D}$ that was nearly six-fold the increase observed in the mutant strain. Although $\mathrm{M}(\mathrm{D} 5+\mathrm{I} 0.1)$ induced no significant effect on $T \_$mutant, it was responsible for a $150 \%$ increase of doubling-time in the wild strain. Similar impacts were expected on the mutant strain after irgarol $0.5 \mu \mathrm{g} . \mathrm{L}^{-1}, \mathrm{M}(\mathrm{D} 5+\mathrm{I} 0.5)$ and $\mathrm{M}(\mathrm{D} 1+\mathrm{I} 0.5)$ exposures, because they all contained the same concentration of irgarol. In fact, after $\mathrm{M}(\mathrm{D} 5+\mathrm{I} 0.5)$ exposure, the increase in $\mathrm{T}_{\mathrm{D}}$ of $T_{-}$mutant was three-fold higher than with irgarol $0.5 \mu \mathrm{g} . \mathrm{L}^{-1}$ alone. As observed to a higher extent in the wild strain, the strongest mixture resulted in amplified effects in the mutant strain as compared to single molecules. This implies that even if diuron alone was not toxic to the mutant strain, at $5 \mu \mathrm{g} . \mathrm{L}^{-1}$ it seemed to somehow increase the toxicity of irgarol $0.5 \mu \mathrm{g} . \mathrm{L}^{-1}$. This might be the result of a synergistic effect between these two compounds, but further investigations would be needed to prove this, using a wider range of concentrations in order to apply the CA model. As reviewed by Cedergreen (2014), binary mixtures of PSII inhibitor antifouling agents were mostly responsible for additive or synergistic effects on autotrophic organisms. The present results indicate such synergy also probably occurs with resistant variants, confirming the existence of some interactions between these compounds that are not limited to the known mode of action. From the mutation revealed by sequencing, it is assumed that diuron cannot bind efficiently to the $\mathrm{Q}_{\mathrm{B}}$ niche of the mutant strain. There could be chemical interactions between the two molecules: diuron might facilitate the binding of irgarol with its target. The mechanisms explaining such interactions between these PSII inhibitors remain to be demonstrated (Cedergreen, 2014).

To our knowledge, no other such experiments involving wild and mutant strains exposed to single herbicides and mixtures have yet been performed elsewhere.

On the one hand, the wild strain was obviously more sensitive to the mixtures containing $5 \mu$ g. $\mathrm{L}^{-1}$ diuron: $\mathrm{M}(\mathrm{D} 5+\mathrm{I} 0.5)$ and $\mathrm{M}(\mathrm{D} 5+\mathrm{I} 0.1)$. On the other hand, due to its resistance to diuron, the mutant strain was more sensitive to mixtures containing $0.5 \mu \mathrm{g} . \mathrm{L}^{-1}$ irgarol. Effects of mixtures and single herbicides can be ranked from the most toxic to the least toxic for the two strains as follows:

T_wild: $\mathrm{M}(\mathrm{D} 5+\mathrm{I} 0.5)>\mathrm{M}(\mathrm{D} 5+\mathrm{I} 0.1) \approx \mathrm{D} 5 \geq \mathrm{M}(\mathrm{D} 1+\mathrm{I} 0.5)>\mathrm{I} 0.5$

T_mutant: $\mathrm{M}(\mathrm{D} 5+\mathrm{I} 0.5)>\mathrm{M}(\mathrm{D} 1+\mathrm{I} 0.5) \geq \mathrm{I} 0.5$

This study demonstrates the great interest of comparing the responses of sensitive and resistant strains exposed to mixtures, in order to figure out what biochemical interactions could lead to an increased toxicity when substances are mixed, especially for resistant strains. 


\section{Conclusions}

Significant effects were induced by exposure of two marine microalgal species to diuron $5 \mu \mathrm{g} . \mathrm{L}^{-1}$ and irgarol $0.5 \mu \mathrm{g} . \mathrm{L}^{-1}$, showing the higher toxicity of irgarol, which was harmful at a tenth the concentration of diuron. Wild strains of $C$. calcitrans and T. suecica did not have the same sensitivity towards the molecules (alone or in mixtures), the first being more sensitive to irgarol $0.5 \mu \mathrm{g} . \mathrm{L}^{-1}$ and the second being more sensitive to diuron $5 \mu \mathrm{g} . \mathrm{L}^{-1}$.

The mutation identified as a single nucleotide change in the $p s b A$ sequence of a $T$. suecica strain that was resistant to diuron was effective against diuron alone, but failed to confer resistance against irgarol exposure. Thus, unlike the wild strain, the mutant strain was more sensitive to irgarol. In addition, the exposure of the mutant strain to the mixture containing irgarol $0.5 \mu \mathrm{g} . \mathrm{L}^{-1}$ and diuron $5 \mu \mathrm{g} . \mathrm{L}^{-1}$, induced stronger effects on growth than irgarol alone. This study, involving a comparison between a wild and a mutant strain of the species $T$. suecica exposed to two PSII inhibitors, highlighted the fact that: i) a particular mutation was not effective to induce resistance to two molecules from different chemical families; ii) a mutant strain, despite its resistance to one of the molecules tested, could also be subjected to probable additive/synergistic effects; iii) biochemical interactions took place inside the cells between the two molecules, which were, at least for diuron, not directly linked to its binding to $\mathrm{Q}_{\mathrm{B}}$ niche.

This study provides new insights into understanding how pollution in aquatic environment can affect unicellular primary producers, by comparing effects of single-herbicide and mixture exposure towards different species, including a mutant strain resistant to diuron. In addition to the identification of the mutation, further investigations on exposure of this mutant strain to pollutants (gene expression and, epigenetic mechanisms) would help us to improve understanding of the mechanisms of microalgal adaptation to chronic contamination.

\section{Acknowledgements}

This study was carried out with financial support from the French National Research Agency (ANR) as part of the Investments for the Future program, within the Cluster of Excellence COTE (ANR-10-LABX-45). We also want to thank Julien Rouxel for his technical assistance and Hansy Haberkorn for his helpful discussions and suggestions during preparation of the manuscript. We thank Helen McCombie for the English correction. We also thank four anonymous reviewers for their comments, which helped us to improve the quality of this manuscript.

\section{References}

Abou-Waly, H.F., 2000. Effect of organic solvents on growth of freshwater algae. Int. J. Environ. Stud. 57, 411. doi:10.1080/00207230008711285

Akimoto, S., Mimuro, M., 2007. Application of Time-Resolved Polarization Fluorescence Spectroscopy in the Femtosecond Range to Photosynthetic Systems†. Photochem. Photobiol. 83, 163-170. doi:10.1562/200602-28-IR-825

Auby, I., Maurer, D., 2004. Étude de la reproduction de l'huître creuse dans le Bassin d'Arcachon : rapport final. $327 \mathrm{p}$.

Bao, V.W.W., Leung, K.M.Y., Qiu, J.W., Lam, M.H.W., 2011. Acute toxicities of five commonly used antifouling booster biocides to selected subtropical and cosmopolitan marine species. Mar. Pollut. Bull. 62, 
Basheer, C., Tan, K.S., Lee, H.K., 2002. Organotin and Irgarol-1051 contamination in Singapore coastal waters. Mar. Pollut. Bull. 44, 697-703. doi:10.1016/S0025-326X(01)00330-7

Borgert, C.J., Quill, T.F., McCarty, L.S., Mason, A.M., 2004. Can mode of action predict mixture toxicity for risk assessment? Toxicol. Appl. Pharmacol. 201, 85-96. doi:10.1016/j.taap.2004.05.005

Brennan, L., Blanco Fernández, A., Mostaert, A.S., Owende, P., 2012. Enhancement of BODIPY 505/515 lipid fluorescence method for applications in biofuel-directed microalgae production. J. Microbiol. Methods 90, 137-143. doi:10.1016/j.mimet.2012.03.020

Buma, A.G.J., Sjollema, S.B., van de Poll, W.H., Klamer, H.J.C., Bakker, J.F., 2009. Impact of the antifouling agent Irgarol 1051 on marine phytoplankton species. J. Sea Res. 61, 133-139. doi:10.1016/j.seares.2008.11.007

Caquet, T., Roucaute, M., Mazzella, N., Delmas, F., Madigou, C., Farcy, E., Burgeot, T., Allenou, J.P., Gabellec, R., 2013. Risk assessment of herbicides and booster biocides along estuarine continuums in the Bay of Vilaine area (Brittany, France). Environ. Sci. Pollut. Res. 20, 651-666. doi:10.1007/s11356-012-1171-y

Carrera-Martinez, D., Mateos-Sanz, A., Lopez-Rodas, V., Costas, E., 2011. Adaptation of microalgae to a gradient of continuous petroleum contamination. Aquat. Toxicol. 101, 342-350. doi:10.1016/j.aquatox.2010.11.009

Cedergreen, N., 2014. Quantifying synergy: A systematic review of mixture toxicity studies within environmental toxicology. PLoS One 9. doi:10.1371/journal.pone.0096580

Chesworth, J.C., Donkin, M.E., Brown, M.T., 2004. The interactive effects of the antifouling herbicides Irgarol 1051 and Diuron on the seagrass Zostera marina (L.). Aquat. Toxicol. 66, $293-305$. doi:10.1016/j.aquatox.2003.10.002

Cooper, M.S., Hardin, W.R., Petersen, T.W., Cattolico, R.A., 2010. Visualizing "green oil" in live algal cells. J. Biosci. Bioeng. 109, 198-201. doi:10.1016/j.jbiosc.2009.08.004

Costas, E., Carrillo, E., Ferrero, L.M., Agrelo, M., Garcia-Villada, L., Juste, J., López-Rodas, V., 2001. Mutation of algae from sensitivity to resistance against environmental selective agents: the ecological genetics of Dictyosphaerium chlorelloides (Chlorophyceae) under lethal doses of 3-(3,4-dichlorophenyl)-1, 1dimethylurea herbicide. Phycologia 40, 391-398. doi:10.2216/i0031-8884-40-5-391.1

Cozic, V., Durand, G., 2013. Mission d'étude pour réduire les impacts du carénage sur le milieu marin. Rapport phase 2 : Evaluer les équipements existants (cales et aires de carénage avec systèmes de traitement). 76 p.

Devilla, R.A., Brown, M.T., Donkin, M., Tarran, G.A., Aiken, J., Readman, J.W., 2005. Impact of antifouling booster biocides on single microalgal species and on a natural marine phytoplankton community. Mar. Ecol. Prog. Ser. 286, 1-12. doi:10.3354/meps286001

Erickson, J.M., Rahire, M., Rochaix, J.D., Mets, L., 1985. Herbicide resistance and cross-resistance: changes at three distinct sites in the herbicide-binding protein. Science. 228, $204-207$. doi:10.1126/science.228.4696.204

Erickson, J.M., Pfister, K., Rahire, M., Togasaki, R.K., Mets, L., Rochaix, J.D., 1989. Molecular and biophysical analysis of herbicide-resistant mutants of Chlamydomonas reinhardtii: structure-function relationship of the photosystem II D1 polypeptide. Plant Cell 1, 361-371. doi:10.1105/tpc.1.3.361

Eriksson, K.M., Clarke, A.K., Franzen, L.G., Kuylenstierna, M., Martinez, K., Blanck, H., 2009. Communitylevel analysis of psbA gene sequences and irgarol tolerance in marine periphyton. Appl. Environ. Microbiol. 75, 897-906. doi:10.1128/AEM.01830-08

Fernández-Alba, A.R., Piedra, L., Mezcua, M., Hernando, M.D., 2002. Toxicity of single and mixed contaminants in seawater measured with acute toxicity bioassays. ScientificWorldJournal. 2, 1115-1120. doi:10.1100/tsw.2002.221

Fuerst, E.P., Norman, M.A., 1991. Interactions of herbicides with photosynthetic electron transport. Weed Sci. 458-464.

Galloway, R.E., Mets, L.J., 1984. Atrazine, Bromacil, and Diuron Resistance in Chlamydomonas1. Plant Physiol. 74, 469-474. 
Gatidou, G., Thomaidis, N.S., 2007. Evaluation of single and joint toxic effects of two antifouling biocides, their main metabolites and copper using phytoplankton bioassays. Aquat. Toxicol. 85, 184-191. doi:10.1016/j.aquatox.2007.09.002

Gatidou, G., Thomaidis, N.S., Zhou, J.L., 2007. Fate of Irgarol 1051, diuron and their main metabolites in two UK marine systems after restrictions in antifouling paints. Environ. Int. 33, 70-77. doi:10.1016/j.envint.2006.07.002

Geissbühler, H., Martin, H., Voss, G., 1975. The substituted ureas, in: Kearney, P.C., Kaufman, D.D. (Eds.), Herbicides: Chemistry, Degradation, and Mode of Action, Vol. 1. Marcel Dekker, New York, pp. 209291.

Giardi, M.T., Pace, E., 2005. Photosynthetic proteins for technological applications. Trends Biotechnol. 23, 257263. doi:10.1016/j.tibtech.2005.03.003

Gramatica, P., Vighi, M., Consolaro, F., Todeschini, R., Finizio, A., Faust, M., 2001. QSAR approach for the selection of congeneric compounds with a similar toxicological mode of action. Chemosphere 42, 873883. doi:10.1016/S0045-6535(00)00180-6

Guillard, R.R.L., Ryther, J.H., 1962. Studies of marine planktonic diatoms. I. Cyclotella nana Hustedt and Detonula confervacea (Cleve) Gran. Can. J. Microbiol. 8, 229-239. doi:10.1139/m62-029

Guillard, R.R.L., 1975. Culture of Phytoplankton for Feeding Marine Invertebrates, in: Smith, W., Chanley, M. (Eds.), Culture of Marine Invertebrate Animals SE - 3. Springer US, pp. 29-60. doi:10.1007/978-1-46158714-9_3

Holmes, G., 2012. Diuron and the Great Barrier Reef - A review of the latest science.

Hu, Q., Sommerfeld, M., Jarvis, E., Ghirardi, M., Posewitz, M., Seibert, M., Darzins, A., 2008. Microalgal triacylglycerols as feedstocks for biofuel production: perspectives and advances. Plant J. 54, 621-639. doi:10.1111/j.1365-313X.2008.03492.X

Huertas, I.E., Rouco, M., López-Rodas, V., Costas, E., 2010. Estimating the capability of different phytoplankton groups to adapt to contamination: Herbicides will affect phytoplankton species differently. New Phytol. 188, 478-487. doi:10.1111/j.1469-8137.2010.03370.x

Jones, R.J., Kerswell, A.P., 2003. Phytotoxicity of Photosystem II (PSII) herbicides to coral. Mar. Ecol. Prog. Ser. 261, 149-159. doi:10.3354/meps261149

Koutsaftis, A., Aoyama, I., 2006. The interactive effects of binary mixtures of three antifouling biocides and three heavy metals against the marine algae Chaetoceros gracilis. Environ. Toxicol. 21, 432-439. doi:10.1002/tox.20202

Lardans, A., Förster, B., Prásil, O., Falkowski, P.G., Sobolev, V., Edelman, M., Osmond, C.B., Gillham, N.W., Boynton, J.E., 1998. Biophysical, biochemical, and physiological characterization of Chlamydomonas reinhardtii mutants with amino acid substitutions at the Ala251 residue in the D1 protein that result in varying levels of photosynthetic competence. J. Biol. Chem. 273, 11082-91. doi:10.1074/jbc.273.18.11082

Larras, F., Montuelle, B., Bouchez, A., 2013. Assessment of toxicity thresholds in aquatic environments: Does benthic growth of diatoms affect their exposure and sensitivity to herbicides? Sci. Total Environ. 463-464, 469-477. doi:10.1016/j.scitotenv.2013.06.063

Larras, F., Keck, F., Montuelle, B., Rimet, F., Bouchez, A., 2014. Linking diatom sensitivity to herbicides to phylogeny: A step forward for biomonitoring? Environ. Sci. Technol. 48, 1921-1930. doi:10.1021/es4045105

Lewis, S.E., Brodie, J.E., Bainbridge, Z.T., Rohde, K.W., Davis, A.M., Masters, B.L., Maughan, M., Devlin, M.J., Mueller, J.F., Schaffelke, B., 2009. Herbicides: A new threat to the Great Barrier Reef. Environ. Pollut. 157, 2470-2484. doi:10.1016/j.envpol.2009.03.006

Loewe, S., Muischnek, H., 1926. Combinated effects I Announcement-Implements to the problem. Naunyn. Schmiedebergs. Arch. Exp. Pathol. Pharmakol. 114, 313-326.

Loos, R., Gawlik, B.M., Locoro, G., Rimaviciute, E., Contini, S., Bidoglio, G., 2009. EU-wide survey of polar organic persistent pollutants in European river waters. Environ. Pollut. 157, 561-8. doi:10.1016/j.envpol.2008.09.020

Loos, R., Locoro, G., Comero, S., Contini, S., Schwesig, D., Werres, F., Balsaa, P., Gans, O., Weiss, S., Blaha, L., Bolchi, M., Gawlik, B.M., 2010. Pan-European survey on the occurrence of selected polar organic persistent pollutants in ground water. Water Res. 44, 4115-26. doi:10.1016/j.watres.2010.05.032 
Lopez-Rodas, V., Agrelo, M., Carrillo, E., Ferrero, L., Larrauri, A., Martín-Otero, L., Costas, E., 2001. Resistance of microalgae to modern water contaminants as the result of rare spontaneous mutations. Eur. J. Phycol. 36, 179-190. doi:10.1080/09670260110001735328

López-Rodas, V., Carrera-Martínez, D., Salgado, E., Mateos-Sanz, A., Báez, J.C., Costas, E., 2009. A fascinating example of microalgal adaptation to extreme crude oil contamination in a natural spill in Arroyo Minero, Río Negro, Argentina. An. la Real Acad. Nac. Farm. 75, 883-889.

Magnusson, M., Heimann, K., Negri, A.P., 2008. Comparative effects of herbicides on photosynthesis and growth of tropical estuarine microalgae. Mar. Pollut. Bull. 56, 1545-52. doi:10.1016/j.marpolbul.2008.05.023

Magnusson, M., Heimann, K., Quayle, P., Negri, A.P., 2010. Additive toxicity of herbicide mixtures and comparative sensitivity of tropical benthic microalgae. Mar. Pollut. Bull. 60, 1978-1987. doi:10.1016/j.marpolbul.2010.07.031

Manzo, S., Buono, S., Cremisini, C., 2006. Toxic effects of Irgarol and Diuron on sea urchin Paracentrotus lividus early development, fertilization, and offspring quality. Arch. Environ. Contam. Toxicol. 51, 61-68. doi:10.1007/s00244-004-0167-0

Marvá, F., López-Rodas, V., Rouco, M., Navarro, M., Toro, F.J., Costas, E., Flores-Moya, A., 2010. Adaptation of green microalgae to the herbicides simazine and diquat as result of pre-selective mutations. Aquat. Toxicol. 96, 130-4. doi:10.1016/j.aquatox.2009.10.009

Munaron, D., Tapie, N., Budzinski, H., Andral, B., Gonzalez, J.L., 2012. Pharmaceuticals, alkylphenols and pesticides in Mediterranean coastal waters: Results from a pilot survey using passive samplers. Estuar. Coast. Shelf Sci. 114, 82-92. doi:10.1016/j.ecss.2011.09.009

Nimbal, C.I., Yerkes, C.N., Weston, L.A., Weller, S.C., 1996. Herbicidal Activity and Site of Action of the Natural Product Sorgoleone. Pestic. Biochem. Physiol. 54, 73-83. doi:10.1006/pest.1996.0011

Nyström, B., Becker-Van Slooten, K., Bérard, A., Grandjean, D., Druart, J.C., Leboulanger, C., 2002. Toxic effects of Irgarol 1051 on phytoplankton and macrophytes in Lake Geneva. Water Res. 36, 2020-2028. doi:10.1016/S0043-1354(01)00404-3

Oettmeier, W., 1992. Chapter 9 - Herbicides of photosystem $\{$ II $\}$, in: Barber, J. (Ed.), The Photosystems, Topics in Photosynthesis. Elsevier, Amsterdam, pp. 349-408. doi:http://dx.doi.org/10.1016/B978-0-444-894403.50018-7

Oettmeier, W., 1999. Herbicide resistance and supersensitivity in photosystem II. Cell. Mol. Life Sci. C. 55, 1255-1277. doi:10.1007/s000180050370

Ohad, N., Dekel, A.-S., Hiroyuki, K., Yorinao, I., Itzhak, O., Joseph, H., 1990. Amino Acid Substitutions in the D1 Protein of Photosystem II Affect QB-Stabilization and Accelerate Turnover of D1. Zeitschrift für Naturforsch. C. doi:10.1515/znc-1990-0515

Pennington, F., Guillard, R.R.L., Liaaen-Jensen, S., 1988. Carotenoid Distribution Patterns in Bacillariophyceae (Diatoms). Biochem. Syst. Ecol. 16, 589-592. doi:10.1016/0305-1978(88)90067-1

Readman, J.W., Kwong, L.L.W., Grondin, D., Bartocci, J., Villeneuve, J.P., Mee, L.D., 1993. Coastal water contamination from a triazine herbicide used in antifouling paints. Environ. Sci. Technol. 27, 1940-1942. doi:10.1021/es00046a027

Romero-Lopez, J., Lopez-Rodas, V., Costas, E., 2012. Estimating the capability of microalgae to physiological acclimatization and genetic adaptation to petroleum and diesel oil contamination. Aquat. Toxicol. 124-125, 227-237. doi:10.1016/j.aquatox.2012.08.001

Sachindra, N.M., Sato, E., Maeda, H., Hosokawa, M., Niwano, Y., Kohno, M., Miyashita, K., 2007. Radical scavenging and singlet oxygen quenching activity of marine carotenoid fucoxanthin and its metabolites. J. Agric. Food Chem. 55, 8516-8522. doi:10.1021/jf071848a

Seguin, F., Leboulanger, C., Rimet, F., Druart, J.C., Bérard, A., 2001. Effects of atrazine and nicosulfuron on phytoplankton in systems of increasing complexity. Arch. Environ. Contam. Toxicol. 40, 198-208. doi:10.1007/s002440010164

Stachowski-Haberkorn, S., Jérôme, M., Rouxel, J., Khelifi, C., Rincé, M., Burgeot, T., 2013. Multigenerational exposure of the microalga Tetraselmis suecica to diuron leads to spontaneous long-term strain adaptation. Aquat. Toxicol. 140-141, 380-388. doi:10.1016/j.aquatox.2013.06.016

Suresh Kumar, K., Dahms, H.U., Lee, J.S., Kim, H.C., Lee, W.C., Shin, K.H., 2014. Algal photosynthetic responses to toxic metals and herbicides assessed by chlorophyll a fluorescence. Ecotoxicol. Environ. Saf. 
Tamura, K., Stecher, G., Peterson, D., Filipski, A., Kumar, S., 2013. MEGA6: Molecular evolutionary genetics analysis version 6.0. Mol. Biol. Evol. 30, 2725-2729. doi:10.1093/molbev/mst197

Thomas, K.V., Fileman, T.W., Readman, J.W., Waldock, M.J., 2001. Antifouling paint booster biocides in the UK coastal environment and potential risks of biological effects. Mar. Pollut. Bull. 42, 677-688. doi:10.1016/S0025-326X(00)00216-2

Tischer, W., Strotmann, H., 1977. Relationship between inhibitor binding by chloroplasts and inhibition of photosynthetic electron transport. Biochim. Biophys. Acta 460, 113-125. doi:10.1016/00052728(77)90157-8

Weiner, J.A., DeLorenzo, M.E., Fulton, M.H., 2004. Relationship between uptake capacity and differential toxicity of the herbicide atrazine in selected microalgal species. Aquat. Toxicol. 68, 121-8. doi:10.1016/j.aquatox.2004.03.004

Wildner, G.F., Heisterkamp, U., Trebst, A., 1990. Herbicide cross-resistance and mutations of the psbA gene in Chlamydomonas reinhardtii. Zeitschrift fur Naturforsch. - Sect. C J. Biosci. Naturforsch. C 45, 1142-1150.

Xia, S., Wang, K., Wan, L., Li, A., Hu, Q., Zhang, C., 2013. Production, characterization, and antioxidant activity of fucoxanthin from the marine diatom Odontella aurita. Mar. Drugs 11, 2667-81. doi: $10.3390 / \mathrm{md} 11072667$ 
Click here to download Table: CHEM-S-15-04460_Tables_Revised.doc

Table 1 - Primers used for D1 protein coding sequence amplification end sequencing.

Sequence $\left(5^{\prime}->3^{\prime}\right)$

Product length (bp)

\begin{tabular}{lll}
\hline D1 A Fw & GCTAACTCAATGTGGGCTCG & 498 \\
D1 A Rv & ACCTAAAGGCATACCATCAGAGA & \\
D1 B Fw & ACCCAATCGGTCAAGGTTCA & 578 \\
D1 B Rv & AGCGTTTACAGATGGAGCTTCT & \\
\hline
\end{tabular}


Table 2 - Effects of diuron and irgarol, singly and in mixtures, on C. calcitrans and T. suecica after six-day exposures.

\begin{tabular}{|c|c|c|c|c|c|c|c|c|c|c|c|c|c|c|c|}
\hline & \multicolumn{5}{|c|}{ Diuron $\left(\mu \mathrm{g} \cdot \mathrm{L}^{-1}\right)$} & \multicolumn{5}{|c|}{ Irgarol $\left(\mu \mathrm{g} \cdot \mathrm{L}^{-1}\right)$} & \multicolumn{5}{|c|}{ Mixtures } \\
\hline & & $T_{D}\left(h^{-1}\right)$ & $\phi^{\prime} \mathrm{M}$ & $\begin{array}{l}\text { FL1 } 1_{\text {ROS }} \\
\left(10^{3} \text { a.u. }\right)\end{array}$ & $\begin{array}{l}\text { FL1 Lipids } \\
\left(10^{3} \text { a.u. }\right)\end{array}$ & & $T_{D}\left(h^{-1}\right)$ & $\phi^{\prime}{ }_{M}$ & $\begin{array}{c}\mathrm{FL} 1_{\text {ROS }} \\
\text { (10 a.u.) }\end{array}$ & $\begin{array}{l}\text { FL1 Lipids } \\
\left(10^{3} \text { a.u. }\right)\end{array}$ & & $T_{D}\left(h^{-1}\right)$ & $\phi^{\prime}{ }_{M}$ & $\begin{array}{c}\text { FL1 } \\
\left(10^{3} \text { a.u. }\right. \\
\end{array}$ & $\begin{array}{l}\text { FL1 } 1_{\text {Lipids }} \\
\left(10^{3} \text { a.u. }\right.\end{array}$ \\
\hline \multirow{4}{*}{ C_wild } & C & $\begin{array}{c}18.2 \pm 0.1 \\
a \\
\end{array}$ & $\begin{array}{c}0.74 \pm 0.002 \\
a \\
\end{array}$ & $\begin{array}{c}1.61 \pm 0.05 \\
a \\
\end{array}$ & $\begin{array}{c}371 \pm 20 \\
a\end{array}$ & C & $\begin{array}{c}16.7 \pm 0.1 \\
a \\
\end{array}$ & $\begin{array}{c}0.74 \pm 0.003 \\
a \\
\end{array}$ & $\begin{array}{c}1.89 \pm 0.17 \\
a\end{array}$ & $\begin{array}{c}420 \pm 46 \\
a\end{array}$ & C & $\begin{array}{c}18.2 \pm 0.1 \\
a \\
\end{array}$ & $\begin{array}{c}0.74 \pm 0.002 \\
a\end{array}$ & $\begin{array}{c}1.61 \pm 0.05 \\
a\end{array}$ & $\begin{array}{c}371 \pm 20 \\
a\end{array}$ \\
\hline & D0.5 & $\begin{array}{c}18.3 \pm 0.1 \\
a\end{array}$ & $\begin{array}{c}0.73 \pm 0.013 \\
a\end{array}$ & $\begin{array}{c}1.63 \pm 0.22 \\
a\end{array}$ & $\begin{array}{c}381 \pm \\
103 \\
a\end{array}$ & 10.05 & $\begin{array}{c}16.9 \pm 0.3 \\
a\end{array}$ & $\begin{array}{c}0.73 \pm 0.004 \\
a\end{array}$ & $\begin{array}{c}1.36 \pm 0.29 \\
a b\end{array}$ & $\begin{array}{c}376 \pm 38 \\
a\end{array}$ & $M(D 5+10.5)$ & $\begin{array}{c}34.0 \pm 2.0 \\
b\end{array}$ & $\begin{array}{c}0.55 \pm 0.006 \\
d\end{array}$ & $\begin{array}{c}0.62 \pm 0.01 \\
b\end{array}$ & $\begin{array}{c}142 \pm 16 \\
b\end{array}$ \\
\hline & D1 & $\begin{array}{c}18.1 \pm 0.1 \\
a\end{array}$ & $\begin{array}{c}0.73 \pm 0.009 \\
a \\
\end{array}$ & $\begin{array}{c}1.79 \pm 0.23 \\
a\end{array}$ & $\begin{array}{c}468 \pm 70 \\
a \\
\end{array}$ & 10.1 & $\begin{array}{c}17.1 \pm 0.2 \\
a\end{array}$ & $\begin{array}{c}0.73 \pm 0.001 \\
a \\
\end{array}$ & $\begin{array}{c}1.50 \pm 0.31 \\
a b\end{array}$ & $\begin{array}{c}322 \pm 3 \\
a \\
\end{array}$ & $\mathrm{M}(\mathrm{D} 5+10.1)$ & $\begin{array}{c}24.5 \pm 1.1 \\
d\end{array}$ & $\begin{array}{c}0.64 \pm 0.02 \\
b\end{array}$ & $\begin{array}{c}0.64 \pm 0.02 \\
b\end{array}$ & $\begin{array}{c}142 \pm 9 \\
b\end{array}$ \\
\hline & D5 & $\begin{array}{c}22.1 \pm 0.4 \\
b\end{array}$ & $\begin{array}{c}0.68 \pm 0.003 \\
b\end{array}$ & $\begin{array}{c}0.71 \pm 0.02 \\
b\end{array}$ & $\begin{array}{c}133 \pm 21 \\
b\end{array}$ & 10.5 & $\begin{array}{c}25.5 \pm 0.5 \\
b\end{array}$ & $\begin{array}{c}0.6 \pm 0.004 \\
b\end{array}$ & $\begin{array}{c}0.66 \pm 0.01 \\
b\end{array}$ & $\begin{array}{c}328 \pm 20 \\
a\end{array}$ & $\mathrm{M}(\mathrm{D} 1+10.5)$ & $\begin{array}{c}28.5 \pm 0.4 \\
c \\
18.6 \pm 0.2 \\
a \\
\end{array}$ & $\begin{array}{c}0.59 \pm 0.004 \\
c \\
0.74 \pm 0.002 \\
a \\
\end{array}$ & $\begin{array}{c}0.64 \pm 0.00 \\
b \\
1.66 \pm 0.21 \\
a \\
\end{array}$ & $\begin{array}{c}134 \pm 12 \\
\mathrm{~b} \\
193 \pm 24 \\
\mathrm{~b} \\
\end{array}$ \\
\hline \multirow{5}{*}{ T_wild } & C & $\begin{array}{c}24.4 \pm 0.1 \\
a \\
\end{array}$ & $\begin{array}{c}0.75 \pm 0.004 \\
a \\
\end{array}$ & $\begin{array}{c}16.60 \pm 0.34 \\
a\end{array}$ & $\begin{array}{c}791 \pm 24 \\
a \\
\end{array}$ & C & $\begin{array}{c}27.3 \pm 0.5 \\
a \\
\end{array}$ & $\begin{array}{c}0.76 \pm 0.004 \\
a \\
\end{array}$ & $\begin{array}{c}17.70 \pm 0.10 \\
a\end{array}$ & $\begin{array}{c}749 \pm 32 \\
a \\
\end{array}$ & C & $\begin{array}{c}27.3 \pm 0.5 \\
a \\
\end{array}$ & $\begin{array}{c}0.76 \pm 0.004 \\
a \\
\end{array}$ & $\begin{array}{c}17.70 \pm 0.10 \\
a \\
\end{array}$ & $\begin{array}{c}749 \pm 32 \\
a \\
\end{array}$ \\
\hline & D0.5 & $\begin{array}{c}25.4 \pm 0.4 \\
a\end{array}$ & $\begin{array}{c}0.73 \pm 0.01 \\
a\end{array}$ & $\begin{array}{c}16.50 \pm 0.12 \\
a\end{array}$ & $\begin{array}{c}687 \pm 43 \\
b\end{array}$ & 10.05 & $\begin{array}{c}27.3 \pm 0.2 \\
a\end{array}$ & $\begin{array}{c}0.78 \pm 0.002 \\
b\end{array}$ & $\begin{array}{c}15.80 \pm 0.42 \\
b\end{array}$ & $\begin{array}{c}726 \pm 11 \\
a\end{array}$ & $M(D 5+10.5)$ & $\begin{array}{c}124.2 \pm 9.5 \\
d\end{array}$ & $\begin{array}{c}0.54 \pm 0.009 \\
d\end{array}$ & $\begin{array}{c}34.50 \pm 1.40 \\
c\end{array}$ & $\begin{array}{c}475 \pm 19 \\
\mathrm{c}\end{array}$ \\
\hline & D1 & $\begin{array}{c}26.2 \pm 0.5 \\
a\end{array}$ & $\begin{array}{c}0.72 \pm 0.008 \\
a\end{array}$ & $\begin{array}{c}18.30 \pm 0.70 \\
b\end{array}$ & $\begin{array}{c}662 \pm 27 \\
b\end{array}$ & 10.1 & $\begin{array}{c}26.2 \pm 0.2 \\
a\end{array}$ & $\begin{array}{c}0.77 \pm 0.001 \\
a b\end{array}$ & $\begin{array}{c}16.60 \pm 0.53 \\
a b\end{array}$ & $\begin{array}{c}763 \pm 23 \\
a\end{array}$ & $M(D 5+\mid 0.1)$ & $\begin{array}{c}68.1 \pm 2.4 \\
c\end{array}$ & $\begin{array}{c}0.58 \pm 0.004 \\
c\end{array}$ & $\begin{array}{c}31.70 \pm 1.00 \\
b c\end{array}$ & $\begin{array}{c}479 \pm 25 \\
\text { c }\end{array}$ \\
\hline & D5 & $\begin{array}{c}54.8 \pm 5.9 \\
b\end{array}$ & $\begin{array}{c}0.56 \pm 0.013 \\
b\end{array}$ & $\begin{array}{c}23.70 \pm 0.30 \\
c\end{array}$ & $\begin{array}{c}493 \pm 15 \\
c\end{array}$ & 10.5 & $\begin{array}{c}32.5 \pm 0.5 \\
b\end{array}$ & $\begin{array}{c}0.75 \pm 0.005 \\
c\end{array}$ & $\begin{array}{c}25.60 \pm 0.82 \\
c\end{array}$ & $\begin{array}{c}594 \pm 10 \\
b\end{array}$ & $\mathrm{M}(\mathrm{D} 1+10.5)$ & $\begin{array}{c}49.3 \pm 0.6 \\
b \\
\end{array}$ & $\begin{array}{c}0.65 \pm 0.004 \\
b \\
\end{array}$ & $\begin{array}{c}29.40 \pm 0.77 \\
b\end{array}$ & $\begin{array}{c}489 \pm 6 \\
c \\
\end{array}$ \\
\hline & & & & & & & & & & & $\mathrm{M}(\mathrm{D} 1+\mathrm{I0.1})$ & $\begin{array}{c}28.8 \pm 0.8 \\
a\end{array}$ & $\begin{array}{c}0.75 \pm 0.003 \\
a\end{array}$ & $\begin{array}{c}19.60 \pm 2.40 \\
a\end{array}$ & $\begin{array}{c}622 \pm 40 \\
b\end{array}$ \\
\hline \multirow{5}{*}{ T_mutant } & C & $\begin{array}{c}29.2 \pm 0.3 \\
a\end{array}$ & $\begin{array}{c}0.76 \pm 0.003 \\
a\end{array}$ & $\begin{array}{c}14.10 \pm 0.53 \\
a\end{array}$ & $\begin{array}{c}885 \pm 20 \\
a\end{array}$ & $\mathrm{C}$ & $\begin{array}{c}29.2 \pm 0.3 \\
a\end{array}$ & $\begin{array}{c}0.76 \pm 0.003 \\
a\end{array}$ & $\begin{array}{c}14.10 \pm 0.53 \\
a\end{array}$ & $\begin{array}{c}885 \pm 20 \\
a\end{array}$ & C & $\begin{array}{c}29.2 \pm 0.3 \\
a\end{array}$ & $\begin{array}{c}0.76 \pm 0.003 \\
a\end{array}$ & $\begin{array}{c}14.10 \pm 0.53 \\
a\end{array}$ & $\begin{array}{c}885 \pm 20 \\
a\end{array}$ \\
\hline & D0.5 & $\begin{array}{c}29.2 \pm 0.3 \\
a\end{array}$ & $\begin{array}{c}0.75 \pm 0.004 \\
a b\end{array}$ & $\begin{array}{c}14.50 \pm 0.56 \\
a\end{array}$ & $\begin{array}{c}901 \pm 17 \\
a\end{array}$ & 10.05 & $\begin{array}{c}28.8 \pm 0.4 \\
a\end{array}$ & $\begin{array}{c}0.74 \pm 0.005 \\
b\end{array}$ & $\begin{array}{c}14.60 \pm 0.27 \\
a\end{array}$ & $\begin{array}{c}851 \pm 26 \\
a\end{array}$ & $M(D 5+10.5)$ & $\begin{array}{c}48.3 \pm 2.0 \\
\mathrm{c}\end{array}$ & $\begin{array}{c}0.65 \pm 0.005 \\
d\end{array}$ & $\begin{array}{c}24.00 \pm 1.10 \\
c\end{array}$ & $\begin{array}{c}738 \pm 17 \\
b\end{array}$ \\
\hline & D1 & $\begin{array}{c}28.7 \pm 1.0 \\
a\end{array}$ & $\begin{array}{c}0.75 \pm 0.003 \\
a b\end{array}$ & $\begin{array}{c}14.20 \pm 0.29 \\
a\end{array}$ & $\begin{array}{c}928 \pm 9 \\
a\end{array}$ & 10.1 & $\begin{array}{c}28.4 \pm 0.3 \\
a\end{array}$ & $\begin{array}{c}0.75 \pm 0.004 \\
a\end{array}$ & $\begin{array}{c}14.80 \pm 0.26 \\
a\end{array}$ & $\begin{array}{c}873 \pm 15 \\
a\end{array}$ & $M(D 5+10.1)$ & $\begin{array}{c}29.1 \pm 0.5 \\
a\end{array}$ & $\begin{array}{c}0.73 \pm 0.007 \\
b\end{array}$ & $\begin{array}{c}15.40 \pm 0.17 \\
a\end{array}$ & $\begin{array}{c}931 \pm 23 \\
a\end{array}$ \\
\hline & D5 & $\begin{array}{c}28.6 \pm 0.1 \\
a\end{array}$ & $\begin{array}{c}0.74 \pm 0.002 \\
b\end{array}$ & $\begin{array}{c}15.30 \pm 0.41 \\
a\end{array}$ & $\begin{array}{c}884 \pm 12 \\
a\end{array}$ & 10.5 & $\begin{array}{c}34.6 \pm 1.0 \\
b\end{array}$ & $\begin{array}{c}0.70 \pm 0.005 \\
c\end{array}$ & $\begin{array}{c}17.00 \pm 0.71 \\
b\end{array}$ & $\begin{array}{c}751 \pm 25 \\
\text { b }\end{array}$ & $\mathrm{M}(\mathrm{D} 1+10.5)$ & $\begin{array}{c}37.4 \pm 0.8 \\
\mathrm{~b}\end{array}$ & $\begin{array}{c}0.70 \pm 0.004 \\
c\end{array}$ & $\begin{array}{c}18.80 \pm 0.34 \\
b\end{array}$ & $\begin{array}{c}786 \pm 41 \\
b\end{array}$ \\
\hline & & & & & & & & & & & $\mathrm{M}(\mathrm{D} 1+\mathrm{I0.1})$ & $\begin{array}{c}28.6 \pm 0.2 \\
a\end{array}$ & $\begin{array}{c}0.74 \pm 0.002 \\
b\end{array}$ & $\begin{array}{c}14.60 \pm 0.34 \\
a\end{array}$ & $\begin{array}{c}897 \pm 10 \\
a\end{array}$ \\
\hline
\end{tabular}


All values are mean values ( \pm standard-error, $\mathrm{SE})$ of raw data

$\mathrm{a}, \mathrm{b}, \mathrm{c}, \mathrm{d}$ indicate significant differences between treatments (ANOVA, $p<0.05$ followed by Newman-Keuls posthoc test, $p<0.05$ )

$\mathrm{T}_{\mathrm{D}}$ : doubling time

$\phi{ }^{\prime}$ : photosystem II effective quantum yield

FL1 $1_{\text {ROS }}$ : intracellular ROS relative content

FL1 $1_{\text {Lipids: }}$ : intracellular lipid relative content

C_wild: C. calcitrans wild strain

T_wild: T. suecica wild strain

T_mutant: T. suecica mutant strain

$\mathrm{C}$ : Control treatment without solvent 
Fig. 1 - Percentage variation of exposed samples of $C$. calcitrans (C_wild) compared with the control treatment without solvent $(C)$ for: doubling time $\left(T_{D}\right)$, photosynthetic efficiency $\left(\phi^{\prime}{ }_{M}\right)$, relative ROS content (FL1 $\left.1_{\mathrm{ROS}}\right)$ and relative lipid content (FL1 $\left.1_{\mathrm{LIPIDS}}\right)$; after exposure to diuron (D) and irgarol (I), alone and in mixtures (means \pm SE). Only significant effects are shown (ANOVA, $p<0.05)$.

Fig. 2 - Percentage variation of exposed samples of $T$. suecica ( $T_{-}$wild) compared with the control treatment without solvent $(C)$ for: doubling time $\left(\mathrm{T}_{\mathrm{D}}\right)$, photosynthetic efficiency $\left(\phi^{\prime}{ }_{\mathrm{M}}\right)$, relative ROS content $\left(F L 1_{R O S}\right)$ and relative lipid content ( $\left.F L 1_{\text {LIPIDS }}\right)$; after exposure to diuron (D) and irgarol (I), alone and in mixtures (means \pm SE). Only significant effects are shown (ANOVA, $p<0.05$ ).

Fig. 3 - Sequence alignments of the mRNA coding for the D1 protein in T. suecica wild and diuron-resistant strains. A: nucleotide sequences; B: translated protein sequences. Dots represent identities, dashes represent unidentified amino acids.

Fig. 4 - Percentage variation of exposed samples of $T$. suecica (T_mutant) compared with the control treatment without solvent $(C)$ for: doubling time $\left(T_{D}\right)$, photosynthetic efficiency $\left(\phi^{\prime}{ }_{M}\right)$, relative ROS content $\left(\mathrm{FL} 1_{\mathrm{ROS}}\right)$ and relative lipid content (FL1 $\left.1_{\text {LIPIDS }}\right)$; after exposure to diuron (D) and irgarol (I), alone and in mixtures (means \pm SE). Only significant effects are shown (ANOVA, $p<0.05)$. 


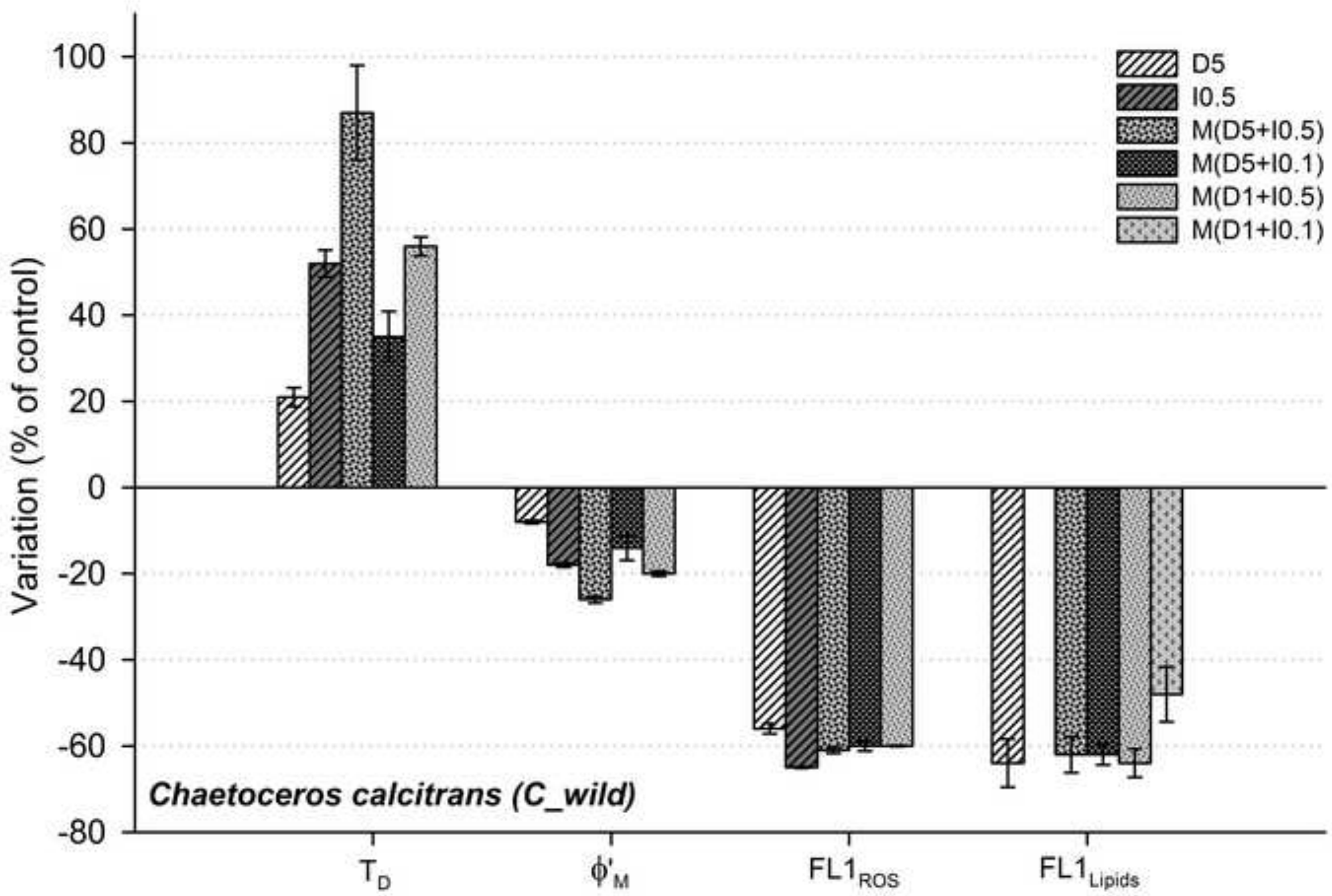




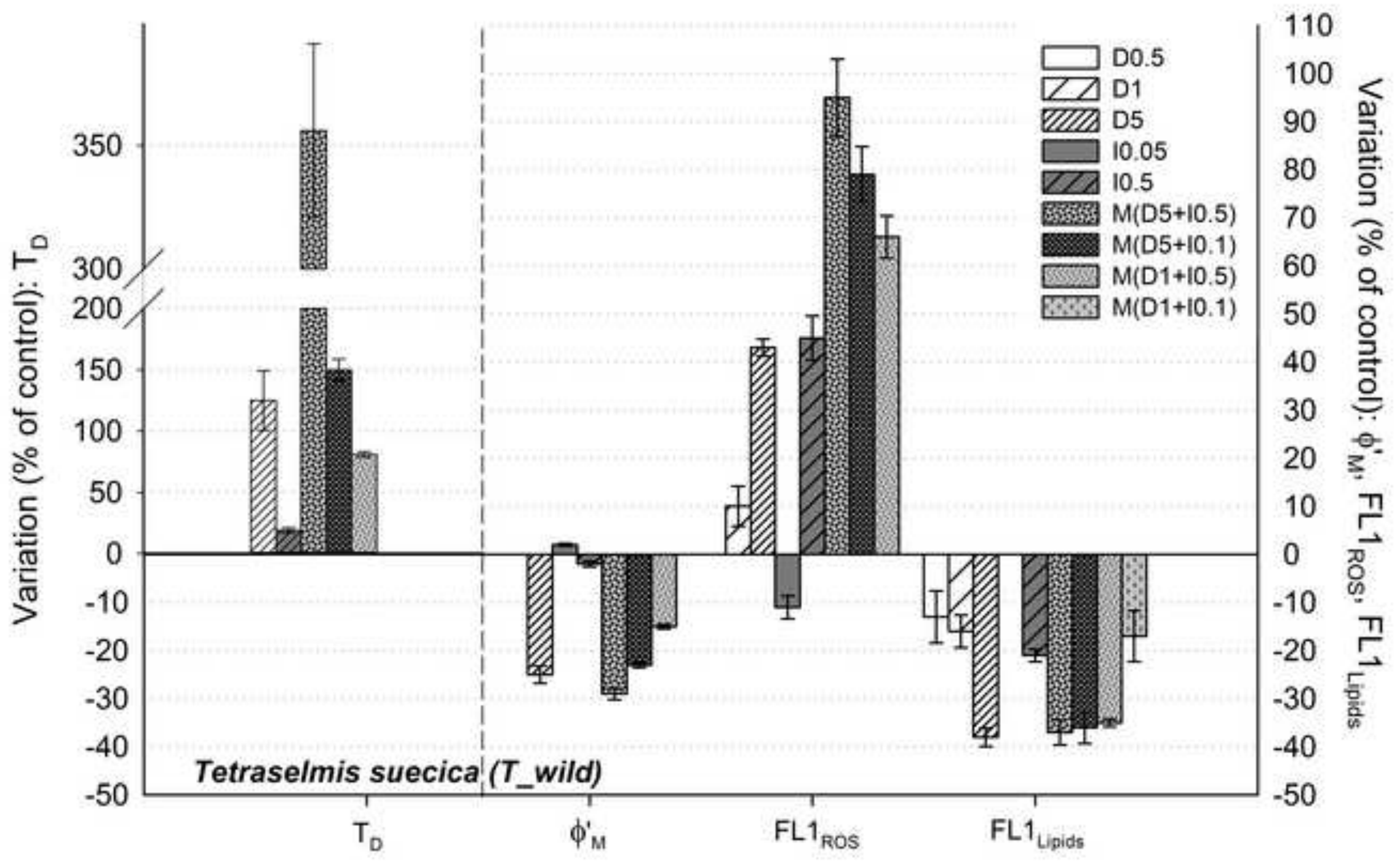


Click here to download high resolution image

A

\begin{tabular}{|c|c|c|}
\hline DQ173249 & 603 & AGGTGTTGCTGGTGTATTTGGTGGTTCATTATTCTCAGCTATGCACGGTTCATTAGTAAC \\
\hline T_wild & 57 & 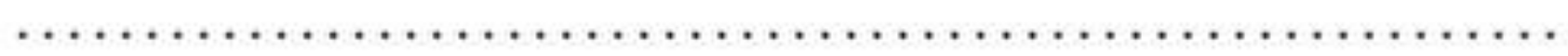 \\
\hline & 52 & 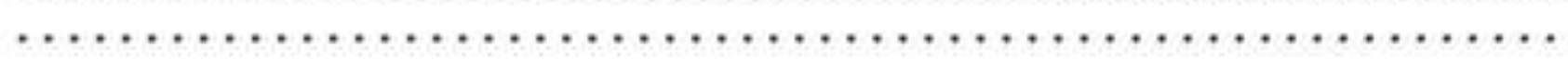 \\
\hline T_wíld & 59 & 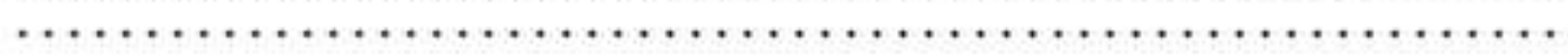 \\
\hline T_wild & 120 & 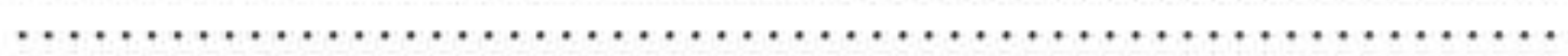 \\
\hline T_wild & 120 & 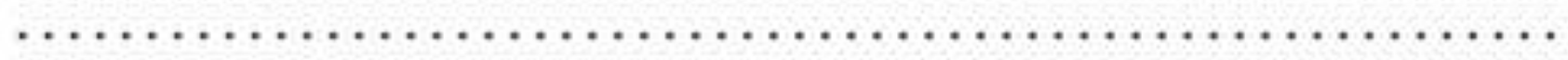 \\
\hline T_wild & 79 & 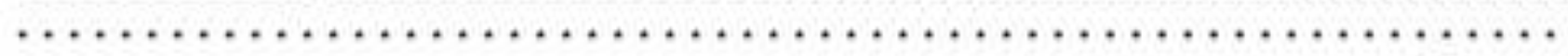 \\
\hline T_mutant & 57 & 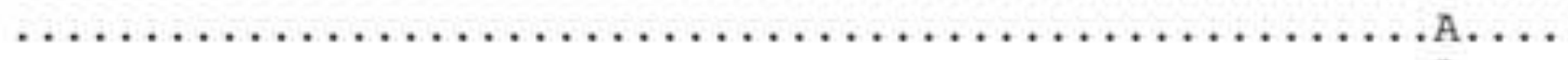 \\
\hline T_mutant & 55 & 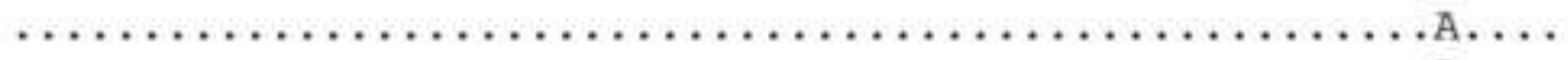 \\
\hline T_mutant & 64 & 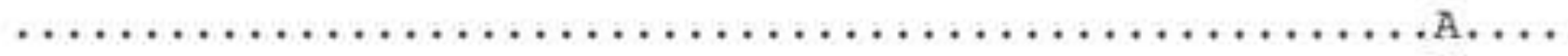 \\
\hline T_mutant & 119 & 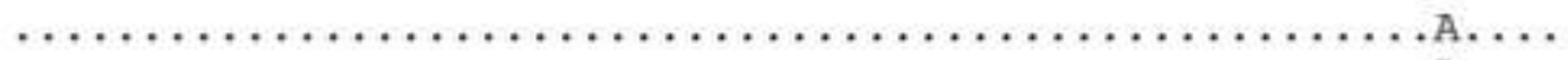 \\
\hline T_mutant & 120 & 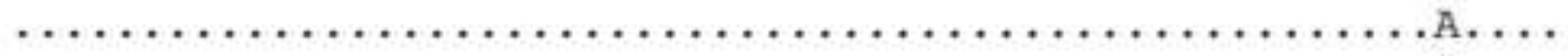 \\
\hline T_mutant & 120 & 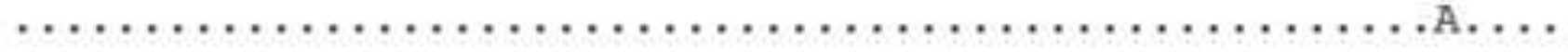 \\
\hline
\end{tabular}

\section{B}

DQ173249 cds T wild

T_wild

T wild

T wild

T wild

T wild

$T$ mutant

$T$ mutant

T mutant

$T$ mutant

$T$ mutant

$T$ mutant

18

3

25

1

25

3

11

2

24

2

25

3

VFQAEHNILMHPFHMLGVAGVFGGSLFSAMHGSLVTSSLIRETTENESANAGYKFGQEEE

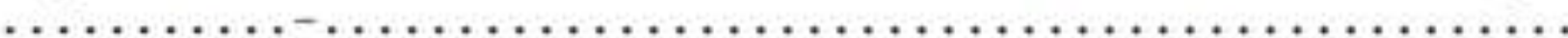




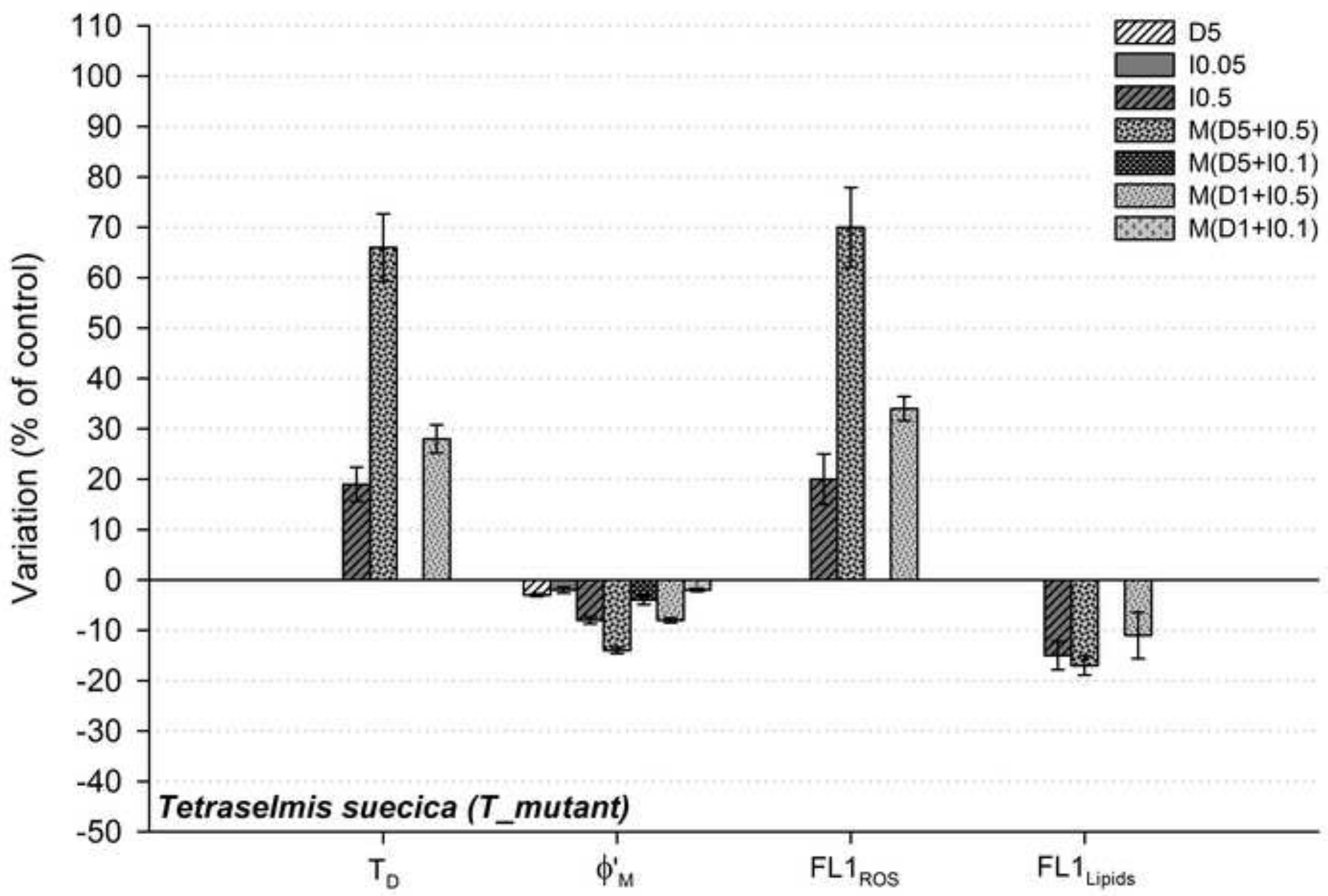


English correction certificate
Click here to download Suppl

Click here to download Supplementary Material: CHEM-S-15-04460_Certificate_correction.pdf

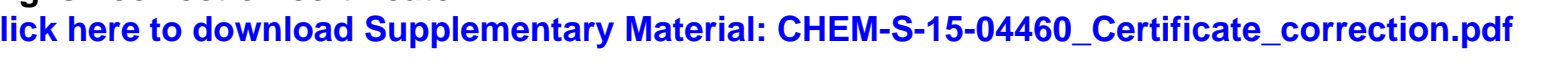

